\title{
Luteinizing Hormone Action in Human Oocyte Maturation and Quality: Signaling Pathways, Regulation, and Clinical Impact
}

\author{
Armando Arroyo ${ }^{1,2} \cdot$ Beomsu Kim ${ }^{3} \cdot$ John Yeh $^{4}$
}

Received: 5 September 2019 / Accepted: 14 October 2019 / Published online: 6 January 2020

(C) The Author(s) 2019

\begin{abstract}
The ovarian follicle luteinizing hormone (LH) signaling molecules that regulate oocyte meiotic maturation have recently been identified. The LH signal reduces preovulatory follicle cyclic nucleotide levels which releases oocytes from the first meiotic arrest. In the ovarian follicle, the LH signal reduces cyclic nucleotide levels via the CNP/NPR2 system, the EGF/EGF receptor network, and follicle/oocyte gap junctions. In the oocyte, reduced cyclic nucleotide levels activate the maturation promoting factor (MPF). The activated MPF induces chromosome segregation and completion of the first and second meiotic divisions. The purpose of this paper is to present an overview of the current understanding of human $\mathrm{LH}$ signaling regulation of oocyte meiotic maturation by identifying and integrating the human studies on this topic. We found 89 human studies in the literature that identified $24 \mathrm{LH}$ follicle/oocyte signaling proteins. These studies show that human oocyte meiotic maturation is regulated by the same proteins that regulate animal oocyte meiotic maturation. We also found that these LH signaling pathway molecules regulate human oocyte quality and subsequent embryo quality. Remarkably, in vitro maturation (IVM) prematuration culture (PMC) protocols that manipulate the LH signaling pathway improve human oocyte quality of cultured human oocytes. This knowledge has improved clinical human IVM efficiency which may become a routine alternative ART for some infertile patients.
\end{abstract}

Keywords Oocyte meiotic maturation $\cdot$ LH follicle signaling $\cdot$ Oocyte quality

\section{Introduction}

Ovarian follicular development and its endocrine function have been the major focus of mammalian ovarian research. Ovarian follicular development has been extensively reviewed

Armando Arroyo

armandoarroyo72@gmail.com

Beomsu Kim

beomsukim@gmail.com

John Yeh

John.yeh.md@gmail.com

1 Boston IVF - The Syracuse Center, 5792 Widewaters Pkwy., Syracuse, NY 13214, USA

2 Department of Obstetrics and Gynecology, SUNY Upstate Medical University, 736 Irving Ave., Syracuse, NY 13210, USA

3 CNY Fertility, 835 Hopkins Rd., Buffalo, NY 14221, USA

4 Department of Obstetrics and Gynecology, Division of Reproductive Endocrinology and Infertility, University of Massachusetts Medical School, 119 Belmont St., Worcester, MA 01655, USA
$[1,2]$. The animal oocyte has received less attention and the human oocyte even less. Pincus reviewed mammalian oogenesis in 1936 [3]. Since these initial studies, much has been learned about the control of oogenesis [4], oocyte maturation [5], oocyte-granulosa cell interactions [6], and cellular organization of the oocyte [7]. Oocyte meiotic maturation is a vital process required for oocyte development. During this process, the LH surge releases oocytes from meiotic prophase arrest and induces resumption of oocyte meiosis and completion of the first meiotic division [8]. This process is initiated when an LH signal is generated in the ovarian follicle. LH binds the mural granulosa cell LH receptor (LHR), activating a G protein which activates the cAMP system. Now, we know that this LH signal targets proteins in both the follicle compartment and the oocyte that regulate oocyte meiotic maturation. The primary targets of the LH signal in the ovarian follicle compartment are the CNP/NPR2 system, the EGF network, and gap junctions $[9,10]$. The primary target of the LH signal in the oocyte is the maturation promoting factor (MPF) [11]. Activation of the MPF phosphorylates the SAC, APC/C systems, and other downstream proteins which induce progression of meiosis, namely germinal vesicle breakdown, 
chromosome condensation, and chromosome segregation. These findings were made in animal models. The cell biology of human oocyte meiotic maturation is less clear.

Oocyte meiotic maturation begins with the mid-cycle LH surge and ends with the formation of a mature oocyte just prior to ovulation (Fig. 1) [12]. The cardinal feature of oocyte meiotic maturation is the formation of a metaphase II-arrested haploid oocyte. LH initiates oocyte meiotic maturation. The induction of oocyte maturation by pituitary gonadotropins was first demonstrated by Heilbrunn in 1939 in frogs. Oocyte maturation begins with the conversion of germinal vesicle (GV) oocytes to MI oocytes then to MII oocytes (Fig. 1). GV oocytes are arrested in prophase I, and may be arrested for up to 50 years in women. The first visible sign of oocyte meiotic maturation is breakdown of the oocyte nuclear membrane referred to as germinal vesicle breakdown (GVBD). This is followed by chromosome condensation and alignment of the chromosomes at the metaphase plate at metaphase I. These oocytes are referred to as metaphase I (MI) oocytes. This is followed by the first oocyte meiotic division, extrusion of the first polar body and formation of a secondary oocyte (mature egg) that arrests at metaphase II until fertilization when the second meiotic division is completed. The molecular mechanisms underlying oocyte meiotic maturation have recently been identified in animals.

LH triggers an explosion of molecular activity in follicle somatic cells $[10,12,13]$. This activates the oocyte maturation promoting factor (MPF) which, in turn, initiates oocyte chromosome segregation. The genesis of the LH signal is the activation of $\mathrm{G}$ protein-coupled receptors in mural granulosa cells by the mid-cycle LH surge causing a cAMP spike in the follicular compartment $[9,14,15]$. This rapidly (20 min) suppresses CNP [16] and NPR2 [17], activates the EGF network, and closes gap junctions. The result is reduced oocyte cGMP levels, activation of phosphodiesterase 3A (PDE3A), reduction of oocyte cAMP levels, activation of CDK1 which initiates resumption of meiosis I, followed by chromosome segregation, completion of the first meiotic division, and the formation of an MII oocyte [11, 18]. The formation of a MII oocyte indicates the completion of final oocyte meiotic maturation which is required for the acquisition of oocyte developmental competence.

Most human oocytes retrieved during in vitro fertilization (IVF) are not developmentally competent to form a viable blastocyst $[19,20]$. It is important to understand how oocytes acquire developmental competence also referred to as oocyte quality during oogenesis since this is the primary factor responsible for reproductive success. A developmentally competent oocyte is able to develop a mature oocyte, fertilize, cleave, form a blastocyst, implant, and develop into a normal fetus. Oocyte quality is acquired during the process of oogenesis which begins in fetal development during the formation of primordial germ cells and primary oocytes, and ends during final oocyte maturation and completion of the second meiotic

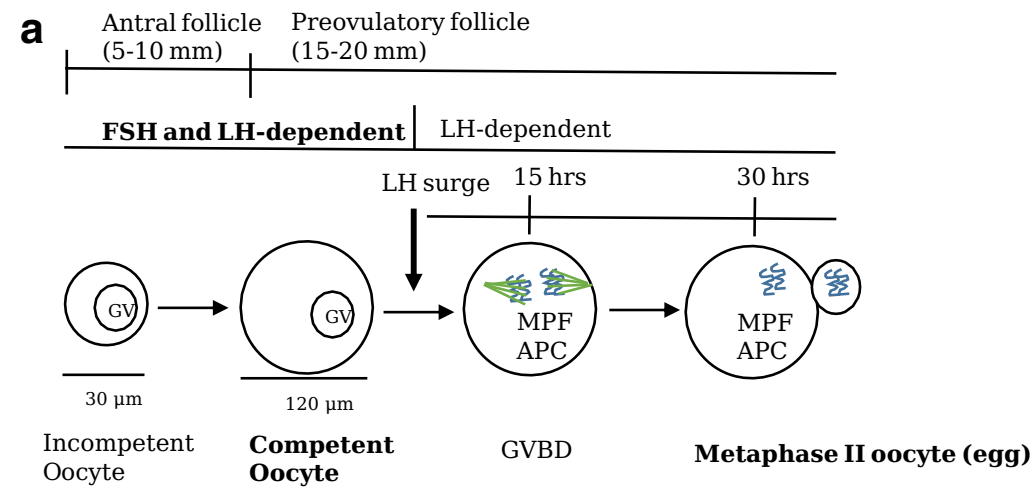

Prophase I arrest Prophase I arrest Metaphase I Metaphase II arrest

Oocyte meiotic maturation

b

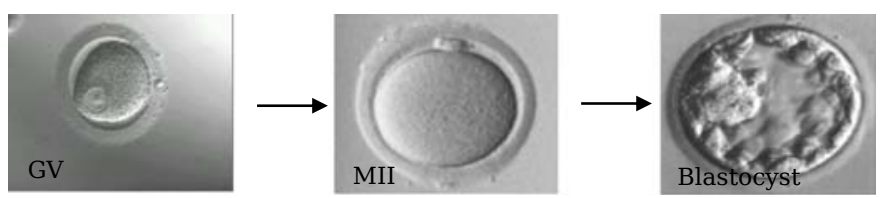

Fig. 1 Human folliculogenesis, oogenesis, and oocyte meiotic maturation. a Gonadotropins regulate folliculogenesis, oogenesis, oocyte meiotic maturation, and oocyte competence. The first visible sign of meiotic progression is oocyte germinal vesicle breakdown (GVBD) followed by expulsion of the first polar body. The mid-cycle LH surge activates the oocyte maturation promoting factor (MPF) which initiates resumption of meiosis. The MPF activates the oocyte anaphase- promoting complex (APC) which promotes completion of the first meiotic division. MII oocytes remain arrested in metaphase II until fertilization induces completion of the second meiotic division. Oocyte meiotic maturation begins with the LH surge and ends at metaphase II. Competent oocytes support the subsequent development of blastocysts. b Human germinal vesicle (GV), MII oocyte (MII), and blastocyst 
division (Fig. 1) [12]. Attainment of oocyte developmental competence requires completion of oocyte cytoplasmic and meiotic maturation [21]. Many cellular processes are responsible for oocyte competence; the major genes responsible for oocyte quality are not yet known $[5,7,22]$.

Very little research has been devoted to the human oocyte due to the lack of available human oocytes for research. Most human oocyte research has occurred in the last 40 years with the more readily available supply of human oocytes from the development of human IVF. Most human oocyte studies obtain research oocytes from IVF clinics. The number of human oocyte publications is still limited, as are reviews on LH signaling in human oocyte meiotic maturation [5, 23, 24].

The purpose of this paper is to provide an updated review on this topic. We found 89 human studies in the literature that identified $24 \mathrm{LH}$ signaling pathway proteins involved in human oocyte meiotic maturation (Table 1). These studies show that these ovarian follicle signaling proteins and oocyte cell cycle proteins not only regulate animal and human oocyte meiotic maturation, but also oocyte competence and embryo quality. In addition, we review studies that demonstrate that human oocyte and embryo quality can be improved by manipulating the LH signaling pathway (Table 2). Experimental human in vitro maturation (IVM) studies that incorporate a prematuration culture (PMC) interval manipulated to maintain high cAMP levels by treating with cAMP phosphodiesterase inhibitors or adenylate cyclase stimulators or supplementing with LH signaling pathway molecules; i.e., AREG improves human oocyte competence and embryo quality [101]. This knowledge has helped to improve clinical human IVM efficiency which now is approaching standard IVF efficiency.

\section{Follicle and Oocyte Development}

The functional unit of the ovary is the follicle. The primary function of the follicle is to support the development of a competent mature oocyte. The follicle contains a single oocyte surrounded by granulosa cells. Follicular growth and development are complex processes that begin in fetal development and end in about 50 years in most women [1]. The oocyte originates from oogonia which arise from primordial germ cells which first appear in the yolk sac around the third week of gestation. Primordial germ cells migrate to the genital ridge around the fifth week of gestation where they divide by mitosis forming approximately 7 million oogonia during the fifth month of gestation. Primary oocytes form from oogonia when they divide by meiosis. Primary oocytes that are surrounded by a single layer of spindle-shaped cells, the precursors of granulosa cells (GCs), are called primordial follicles which
Table 1 LH signaling proteins regulate human oocyte meiotic maturation

\begin{tabular}{lll}
\hline Follicle/oocyte protein & Protein type & Reference(s) \\
\hline Follicle granulosa cell proteins & & \\
1. LH receptor & G protein-coupled receptor & {$[25-33]$} \\
2. Adenylate cyclase 7 and 9 & Enzyme & {$[30]$} \\
3. CNP & Natriuretic peptide & {$[16,34,35]$} \\
4. EGF & Growth factor & {$[35-40]$} \\
5. AREG & Growth factor & {$[33,35,41-46]$} \\
Follicle cumulus cell proteins & & \\
6. NPR2 & Guanylate cyclase & {$[34]$} \\
7. EGF receptor (eRB1) & Tyrosine kinase receptor & {$[35,38]$} \\
8. Cx43 & Channel & {$[47-55]$} \\
9. BMPRII & Serine/threonine kinase & {$[29,56,57]$} \\
10. SMAD2/3 & Transcription factor & {$[56,58-60]$} \\
Oocyte-specific factors & & \\
11. GDF9 & Growth factor & {$[25,61-71]$} \\
12. BMP15 & Growth factor & {$[56,57,72-77]$} \\
Oocyte signaling proteins & & \\
13. GPR3 & G protein-coupled receptor & {$[78]$} \\
14. AC3 & Enzyme & {$[78]$} \\
15. PDE3A & Enzyme & {$[78]$} \\
Oocyte MPF complex (cell cycle control) & Serine/threonine kinase & {$[25,79-81]$} \\
16. CDK1 & Cyclin & {$[81,82]$} \\
17. Cyclin B1 & Serine/threonine kinase & {$[80,83]$} \\
18. WEE1B & Phosphatase & {$[25,84]$} \\
19. CDC25 & Serine/threonine kinase & {$[25,80-82,85-87]$} \\
Oocyte SAC (cell cycle control) & Heterotrimeric G protein & {$[82]$} \\
20. Bub1, BubR1, Bub3 & Ubiquitin ligase & {$[81,82,88]$} \\
21. CDC20 & Protease & {$[81,82,88]$} \\
Chromosome segregation (cell cycle control) & ATPases & {$[81,89-92]$} \\
22. APC (ANAPC1, 4, and 11) & & \\
23. Securin-separase & & \\
24. Cohesin (SMC1, REC8, STAG3) & . & \\
\hline & &
\end{tabular}


appear during the fifth month of gestation in humans. The spindle-shaped cells differentiate into granulosa cells which proliferate transforming the primordial follicle into a primary follicle. A degenerative process called atresia reduces the number of oocytes from seven million to one million at birth to 500,000 at menarche. Primary oocytes, primordial follicles, and primary follicles remain arrested in the diplotene stage of prophase I until puberty when the ovarian cycle begins.

Much of our understanding of follicular development comes from studies of the rodent 4-day estrus cycle. Pedersen described five follicle stages in the mouse ovary: primordial, primary, secondary (preantral), tertiary (antral), and preovulatory (Graafian) [102]. Primordial follicles continuously leave the non-growing oocyte pool starting at puberty. The conversion of dormant primordial follicles to growing primary follicles is a critical step in folliculogenesis. Primary follicles are composed of cuboidal granulosa cells, a basal lamina, and a $20-\mu \mathrm{m}$-diameter primary oocyte. The nature of the converting signal is not yet known [103, 104]. Primary follicles are converted to secondary follicles, and these are composed of two layers of GCs, a zona pellucida, and theca cells. Secondary follicles produce estrogen, progesterone, and androgens and express gap junctions.

The tertiary follicle or antral follicle develops a space filled with follicular fluid called an antrum, which grows reaching a diameter of $2-5 \mathrm{~mm}$. At this stage, 2 million follicle somatic cells, mural granulosa cells (mGCs) and cumulus cells (CCs), surround the oocyte. The theca interna and externa are formed, LH receptors appear, and estrogen becomes the dominant steroid hormone of the follicle as a result of increased follicular steroidogenesis activity. Antral follicle growth is dependent on follicle-stimulating hormone (FSH) and luteinizing hormone (LH). The preovulatory follicle mean diameter is $20 \mathrm{~mm}$ [18-24, 101], and mean follicular volume is $3.8 \mathrm{ml}$ (3.1-8.2). The oocyte at this stage attains a maximum diameter of $70 \mu \mathrm{m}$.

The ovarian cycle refers to three reproductive processes: folliculogenesis, ovulation, and formation of the corpus luteum. Folliculogenesis, which is highly regulated, refers to the process of ovarian follicle growth and differentiation that primarily occurs during the menstrual cycle. Gougeon described five stages of human follicle development based on follicular size and granulosa cell numbers: primordial follicles, primary follicles, secondary follicles, antral follicles, and preovulatory follicles $[105,106]$. The primordial follicle is surrounded by a single layer of pre-granulosa cells, and it has a mean diameter of $30 \mu \mathrm{m}$. They appear in the fetus at 16 weeks gestation. At this stage, follicular growth is gonadotropin independent. Primary follicles contain a single layer of cuboidal GCs, they develop a zona pellucida, and oocyte gap junctions (GJs) appear. They appear at 20 weeks gestation.

In the next stages of maturation, follicle growth becomes gonadotropin dependent. GCs proliferate increasing to 600 , and the oocyte grows resulting in a secondary follicle. At this point, the follicle diameter is $120 \mu \mathrm{m}$, the oocyte diameter increases to $80 \mu \mathrm{m}$, and the germinal vesicle (GV) diameter is $25 \mu \mathrm{m}$. FSH, LH, androgen, and estrogen receptors appear. Theca cells and GJs appear. In the next phase (class 4), follicles grow to a diameter of $2 \mathrm{~mm}, \mathrm{GC}$ proliferation increases to 370,000 , and the antrum appears. This follicle is called a Graafian follicle. The oocyte now has an eccentric position and is surrounded by multiple layers of GC which are called cumulus cells (CCs).

Follicular maturation refers to the formation of the preovulatory follicle from the tertiary follicle which occurs during the 15 days of the follicular phase [106]. In this phase, the antral follicle becomes a preovulatory follicle or dominant follicle, follicle growth becomes exponential, and the oocyte acquires full developmental competence. The follicle size increases from 5 to $20 \mathrm{~mm}$, GC numbers increase from 370,000 to 50 million, and the oocyte diameter increases to $120 \mu \mathrm{m}$. Growth of the dominant follicle is stimulated by FSH, estrogen production increases, the antrum grows, and LH receptors appear.

Oocyte capacitation and final oocyte maturation occur during the first 15 days (follicular phase) of the menstrual cycle [107]. The oocyte reaches its full developmental capacity referred to as full developmental competence during the preovulatory stage prior to the LH surge (Fig. 1). The acquisition of full competence is referred to as oocyte capacitation which is primarily FSH dependent. Oocyte competence is correlated to follicle diameter. Preovulatory follicles with $15-25-\mathrm{mm}$ diameters generally contain competent oocytes. At this point, the oocyte is ready to undergo final oocyte meiotic maturation. The mid-cycle LH surge releases oocytes from prophase arrest and induces chromosome segregation, completion of the first meiotic division, extrusion of the first polar body, and ovulation of the secondary oocyte into the fallopian tube.

The terms recruitment, selection, and dominance describe ovarian follicle maturation during the follicular phase of the menstrual cycle [107]. In the early follicular phase, a cohort of primordial follicles matures while many others degenerate by atresia. This pattern of follicle growth and atresia has been referred to as the "trajectory of follicle growth". The term recruitment refers to the process by which a follicle cohort enters the growth trajectory. Selection refers to the process that reduces the recruited follicle cohort to one follicle. Selection occurs in the early follicular phase. Dominance refers to the one follicle being selected to ovulate [108]. It becomes dominant 7 days before ovulation. Estradiol production increases and becomes the primary steroid in dominant follicles. Estradiol levels are different in the ovarian veins by days 5 to 7 of the cycle [109]. Intrafollicular estradiol levels peak in the dominant follicle in the late follicular phase. This is followed by the mid-cycle LH surge. At the beginning of the LH surge, intrafollicular E2 levels decrease, and progesterone levels increase which reflects GC luteinization [110]. In 
Table 2 Effect of IVM/PMC on human oocyte and embryo quality

\begin{tabular}{|c|c|c|c|c|c|}
\hline & Groups & MII & FR & $\mathrm{CR}$ & $\mathrm{BR}$ \\
\hline \multicolumn{6}{|c|}{ cAMP-modulated IVM systems } \\
\hline $\mathrm{ND},[93]$ & Conventional IVM & $46 \%^{\mathrm{a}}$ & $60 \%$ & & \\
\hline 2006 & PMC-PDE-I & $67 \%^{\mathrm{a}}$ & $58 \%$ & & \\
\hline SYM, [94] & Conventional IVM & $55.6 \%$ & $52 \%{ }^{\mathrm{a}}$ & $16.7 \%$ & $5 \%$ \\
\hline \multirow[t]{3}{*}{2008} & PMC-PDE-I & $59.7 \%$ & $65 \%$ & $20.8 \%$ & $8.7 \%$ \\
\hline & PMC-Forskolin & $62.8 \%$ & $67 \%$ & $15.4 \%$ & $10.2 \%$ \\
\hline & PMC-PDE-I + forskolin & $65.4 \%$ & $76.3 \%^{\mathrm{a}}$ & $23.5 \%$ & $17.6 \%$ \\
\hline VL, [95] & Conventional IVM & $60.6 \%{ }^{\mathrm{a}}$ & $55.0 \%{ }^{\mathrm{a}}$ & $27.3 \%^{\mathrm{a}}$ & \\
\hline 2009 & PMC-ECM, PDE-I & $81.6 \%{ }^{\mathrm{a}}$ & $67.5 \%{ }^{\mathrm{a}}$ & $55.6 \%{ }^{\mathrm{a}}$ & \\
\hline $\begin{array}{l}\text { SC, [96] } \\
2015\end{array}$ & PMC-PDE-I & $50.2 \%$ & $68.3 \%$ & $30.5 \%$ & \\
\hline \multicolumn{6}{|c|}{ Novel IVM systems } \\
\hline GPT, [97] & Cumulus-denuded & & & & \\
\hline \multirow[t]{5}{*}{1998} & wo EGF & $33.9 \%^{\mathrm{b}}$ & $53.8 \%$ & $42.8 \%$ & \\
\hline & w EGF & $64.3 \%^{\mathrm{b}}$ & $72.7 \%$ & $50 \%$ & \\
\hline & Cumulus-intact & & & & \\
\hline & wo EGF & $79 \%$ & $45.6 \%{ }^{\mathrm{a}}$ & $95.2 \%$ & \\
\hline & w EGF & $81 \%$ & $71.7 \%^{\mathrm{a}}$ & $84.8 \%$ & \\
\hline BAI, [98] & Conventional IVM & $36.5 .0 \%{ }^{\mathrm{a}}$ & $73.6 \%$ & $85.7 \%$ & \\
\hline 2011 & IVM-EGF/AREG & $75.5 \%{ }^{\mathrm{a}}$ & $71.8 \%$ & $85.7 \%$ & \\
\hline SF, [99] & Conventional IVM & $48 \%^{\mathrm{c}}$ & $31 \%$ & $23 \%^{\mathrm{c}}$ & $8 \%^{\mathrm{b}}$ \\
\hline 2017 & PMC-CNP + IVM/ARE & $70 \%^{\mathrm{c}}$ & $53 \%$ & $43 \%^{\mathrm{c}}$ & $18 \%^{\mathrm{b}}$ \\
\hline MA, [100] & Standard-IVM & $42 \%^{\mathrm{c}}$ & $76 \%$ & $38 \%^{\mathrm{c}}$ & $40 \%$ \\
\hline \multirow[t]{3}{*}{2018} & AFF-IVM & $34 \%^{\mathrm{c}}$ & $73 \%$ & $36 \%{ }^{\mathrm{c}}$ & $25 \%^{\mathrm{c}}$ \\
\hline & HFF-IVM & $59 \%$ & $80 \%$ & $60 \%$ & $42 \%$ \\
\hline & HFF-CGC-IVM & $79 \%^{\mathrm{c}}$ & $92 \%$ & $71 \%^{\mathrm{c}}$ & $65 \%^{\mathrm{c}}$ \\
\hline
\end{tabular}

$P M C$, prematuration culture; $M I I$, metaphase II; $F R$, fertilization rate; $C R$, cleavage rate; $B R$, blastocyst rate; $P D E-I$, phosphodiesterase inhibitor; $E C M$, extracellular matrix; $w$, with; wo, without; $C N P$, C-natriuretic peptide; $P<0.05^{\mathrm{a}}, P<0.01^{\mathrm{b}}, P<0.001^{\mathrm{c}}$

women, the mid-cycle LH surge triggers GVBD, cumulus cell expansion, and extrusion of the first polar body at 15,22 , and $35 \mathrm{~h}$ after the start of the LH surge, respectively (Fig. 1) [111].

\section{Luteinizing Hormone Receptor}

\section{Mid-cycle Luteinizing Hormone Surge}

The menstrual cycle is under neuroendocrine control. Luteinizing hormone (LH) is a member of the pituitary glycoprotein hormone family which consists of LH, FSH, HCG, and TSH. Each is a heterodimer glycoprotein composed of two non-covalently bound polypeptide subunits. They each contain an identical alpha subunit and a hormone-specific beta subunit. The human $\mathrm{LH} \beta, \mathrm{FSH} \beta$, and $\mathrm{hCG} \beta$ subunits are composed of 121,110 , and 145 amino acids, respectively. The human common $\alpha$ subunit is composed of 92 amino acids. In humans, the LH beta subunit and hCG gene are located on chromosome 19, FSH beta is on chromosome 11, and the common alpha is on chromosome 6. Cloning and DNA sequence of the gene encoding the bovine beta FSH chain were determined in 1986 [112]. Both gonadotropins are synthesized and stored in pituitary gonadotrope granules. Both LH and FSH exist within a single gonadotrope population in the anterior pituitary consistent with the combined secretion of LH and $\mathrm{FSH}$ at mid-cycle in humans.

The onset of the LH surge occurs on cycle day 15 of the menstrual cycle. The LH surge is characterized by a 10 -fold increase in LH levels in the peripheral circulation [113]. The mean duration of the LH surge is 4 days. How serum LH reaches the mural granulosa cells is not clear; however, $\mathrm{LH}$ binds the LH receptor, inducing oocyte maturation and ovulation, 36 and $40 \mathrm{~h}$ respectively, after the beginning of the $\mathrm{LH}$ surge. The mid-cycle LH surge is induced by circulating estrogen. Mean estradiol levels peak at $200 \mathrm{pg} / \mathrm{ml}$ at the end of the follicular phase. This rise in circulating estradiol induces the pituitary LH surge. Estrogen induces the LH surge by acting on the pituitary and hypothalamus. Whether the 
primary action of estrogen is on the pituitary and/or hypothalamus is still not clear.

The pituitary LH surge is controlled by gonadotropinreleasing hormone $(\mathrm{GnRH})$ secreted by hypothalamic $\mathrm{GnRH}$ neurons. How the brain controls the pituitary gland and pituitary gonadotropin secretion was not known until fairly recently. Early studies speculated that a neural factor controls reproduction [114]. Guillemin [115] and Schally [116] simultaneously discovered the neural factor, luteinizing hormonereleasing hormone (LHRH), in 1971. This discovery established the field of neuroendocrinology. The Nobel Prize in Medicine was awarded to Guillemin, Schally, and Yaslow in 1977. Yaslow developed the radioimmunoassay (RIA), a method that utilizes radioactive isotopes to measure hormones and other molecules. Insulin was measured for the first time with the RIA method. A GnRH surge was identified in pituitary stalk blood in rats [117] and primates [118] using the RIA method. The mechanisms underlying the GnRH surge are still not known. Estrogen is probably involved. Estrogen induces a GnRH surge in the ewe [119].

The most important feature of the GnRH system is the inherent pulsatility of GnRH neurons. Many years of research have been devoted to this area [120-123]. GnRH neurons are bipolar neuroendocrine cells that are located in the medial basal hypothalamus. In primates, GnRH neuron cell bodies are primarily located in the medial preoptic area of the hypothalamus, while their axons are primarily found in the median eminence [124]. GnRH is a decapeptide that is stored in GnRH neuron vesicles. The vesicles are transported to the GnRH neuron axon terminals where GnRH is released in a pulsatile fashion into the portal vessels that surround the pituitary gonadotropes. GnRH pulses, in the portal vessels, occur every $30 \mathrm{~min}$ in rats [125] and every $60 \mathrm{~min}$ in primates. The neural mechanism that controls pulsatile GnRH secretion is still not clear [123]. GnRH neuron excitation-secretion coupling may be involved. Isolated GnRH neurons in vitro release $\mathrm{GnRH}$ in a pulsatile fashion [126]. GnRH neurons in vivo generate periodic electrical bursts [127]. Estrogen [128, 129] is probably involved, and GnRH neuron ion channels [130, 131] may have a role. Secreted GnRH binds the GnRH receptors on the pituitary gonadotropes which stimulates cAMP production. This results in increased intracellular calcium which causes the release of LH and FSH. LH and FSH are released into the peripheral circulation in a pulsatile fashion in sheep and rats [132, 133], primates [134], women [135, 136], and men [137]. LH is transported to the ovary where it binds mural granulosa cell LH receptors.

\section{LH Receptor}

The mid-cycle LH surge in humans and animals activates the luteinizing hormone receptor (LHR) also referred to as the luteinizing hormone/choriogonadotropin receptor (LHCGR).
LHR is primarily expressed in the mural granulosa cells of the ovarian follicle. The biological actions of LH, required for oocyte maturation, ovulation, and corpus luteal function, in the ovarian follicle are mediated by LHR which is coupled to Gs, the $G$ protein that activates adenylate cyclase and cAMP. This results in an elevation of follicle cAMP levels which affects multiple follicle LH signaling pathway molecules that ultimately activate the maturation promoting factor (MPF) in the oocyte which induces oocyte maturation, resumption of meiosis, and the first meiotic division.

$\mathrm{LH}$ receptors belong to the rhodopsin/ $\beta 2$-adrenergic receptor subfamily A of G protein-coupled receptors (GPCR). The LH receptor is a seven-transmembrane domain cell surface protein [138-141]. The human $\mathrm{LH} / \mathrm{hCG}$ receptor was cloned in 1995 [142]. It is composed of 701 amino acids, 333 amino acids form the seven transmembrane domain segments, and 341 amino acids form the large extracellular domain. The extracellular domain is the hormone-binding domain. $\mathrm{LH}$ binds the LH receptor extracellular domain causing a conformational change in $\mathrm{G}_{\mathrm{s}} \alpha$ resulting in replacement of GDP with GTP. The GTP $\alpha$ unit activates adenylate cyclase which converts ATP to cAMP [143-145]. LH receptors are expressed exclusively in mural granulosa cells (GCs), and almost no expression is found in cumulus cells (CCs) or the oocyte in rats and mice [146-148].

LH receptor mRNA expression in mural granulosa cells is regulated during the ovarian cycle. Peng et al. found that $\mathrm{LH}$ receptor expression is up and downregulated during the ovarian cycle [149]. In unstimulated rats, LH receptor mRNA expression is not detectable in GC and cumulus granulosa cells. In human menopausal gonadotropin (HMG)-stimulated rats, $\mathrm{LH}$ receptor mRNA expression is highest in mural GC in preovulatory follicles and is undetectable in CCs. Post-HCG, LH receptor expression in mural granulosa cells (mGCs) decreases markedly and again increases in the corpus luteum. The LH surge paradoxically downregulates LH receptor expression in preovulatory follicles [150-155].

The LH surge activates mGC LH receptors, which results in a dramatic increase in follicle cAMP production. Approximately 10,000 LH receptors are expressed in each rat GC in preovulatory follicles [156]. Activation of LH receptors causes a 200-fold increase in cAMP levels in mural GCs, which is referred to as the preovulatory cAMP spike [157]. The cAMP spike transmits the LH signal to the cumulus cells and the oocyte via multiple signaling pathways.

LHR mutations cause follicle development abnormalities and infertility in animals and humans. LHR mutations in mice cause an increase in antral follicles and they lack preovulatory follicles which results in anovulation and infertility. Lei et al. generated LH receptor knockout mice [158]. They are infertile, the internal and external genitalia are severely underdeveloped, the ovaries are small, and the ovarian follicles arrest at the antral follicle stage. Zang et al. also generated LH 
receptor knockout mice [159]. The null mice are infertile, the ovaries are small, and the ovarian follicles grow only to the early antral stage. These studies suggest that LH is required for the development of a dominant preovulatory follicle. Ovarian follicle growth and development beyond the early antral stage require some $\mathrm{LH}$ activation of the $\mathrm{LH}$ receptor.

In humans, LHR is primarily expressed in ovarian follicle granulosa cells [25]. Similar to animals, LH receptor expression is highest in mGCs in preovulatory follicles. LH receptor GC mRNA expression is 10-fold higher in preovulatory follicles compared with small antral follicles [26, 27]. LHR expression is suppressed by the LH surge. The LH surge downregulates GC LH receptor expression in preovulatory follicles in women $[28,29]$. The mid-cycle LH surge activates mural GC LH receptors which activates adenylate cyclase [30] and increases follicle cAMP levels (Fig. 2).

Mutations of LHR cause ovarian follicle development abnormalities and infertility in women. Women with LHR mutations experience amenorrhea, lack preovulatory follicles, do not respond to exogenous HCG, and are infertile [160]. Toledo et al. in 1996 reported a LHR mutation case in a 21-year-old with 46XX primary amenorrhea, normal secondary sexual development, and infertility [161]. Ovary size was normal on ultrasound. Histologic analysis of an ovarian biopsy revealed primordial follicles, preantral follicles, and antral follicles. No preovulatory follicles were seen. DNA analysis of the LHR gene revealed a single nucleotide change (guanine to cytidine at position 1787). This caused a substitution of a proline for an alanine in the LH receptor. Human embryonic kidney cells, transfected with the mutant LH receptor gene, did not respond to HCG.

Latronica et al. reported a 40-year-old with irregular menstrual cycles, normal menarche and pubarche, and infertility [162]. The ovaries were normal size on pelvic ultrasound, the FSH level ranged from 5 to $17 \mathrm{IU} / \mathrm{l}$, the serum estradiol level was $<50 \mathrm{pg} / \mathrm{ml}$, total testosterone was normal, and karyotype was 46XX. A six-nucleotide deletion in the LH receptor gene resulted in deletion of leucine and valine. Cells transfected with the mutated LHR cDNA revealed reduced LHR expression and reduced (1.5- vs. 30-fold in wild-type transfected cells) stimulation of cAMP in response to HCG. These studies show that LHR mutations cause anovulation and infertility. These studies suggest that human early follicle development is primarily FSH dependent, while preovulatory follicle development requires LH. LHR may be abnormal in PCOS. LHR mRNA is overexpressed in GC and theca cells in women with PCOS when compared with normal controls [163].

The LHR mRNA expression in cumulus cells (CCs) may predict oocyte quality. Yang et al. studied LHR mRNA expression in cumulus cells from 35 PCOS women who underwent 50 IVM cycles [31]. Patients were given HCG $10,000 \mathrm{IU}$ on cycle days 7 and 13, and oocytes were retrieved $36 \mathrm{~h}$ post-HCG. Cumulus-oocyte complexes (COCs) were separated into 3 groups: dispersed CCs (group A), compacted CCs (group B), and sparse CCs (group C). Dispersed CCs were enclosed by an expanded CC and 1-2 corona cell layers, compacted CCs contained 4-5 corona cell layers, and sparse $\mathrm{CCs}$ had few coronal cells. COCs were cultured in IVM media supplemented with human follicular fluid (FF), FSH, HCG,

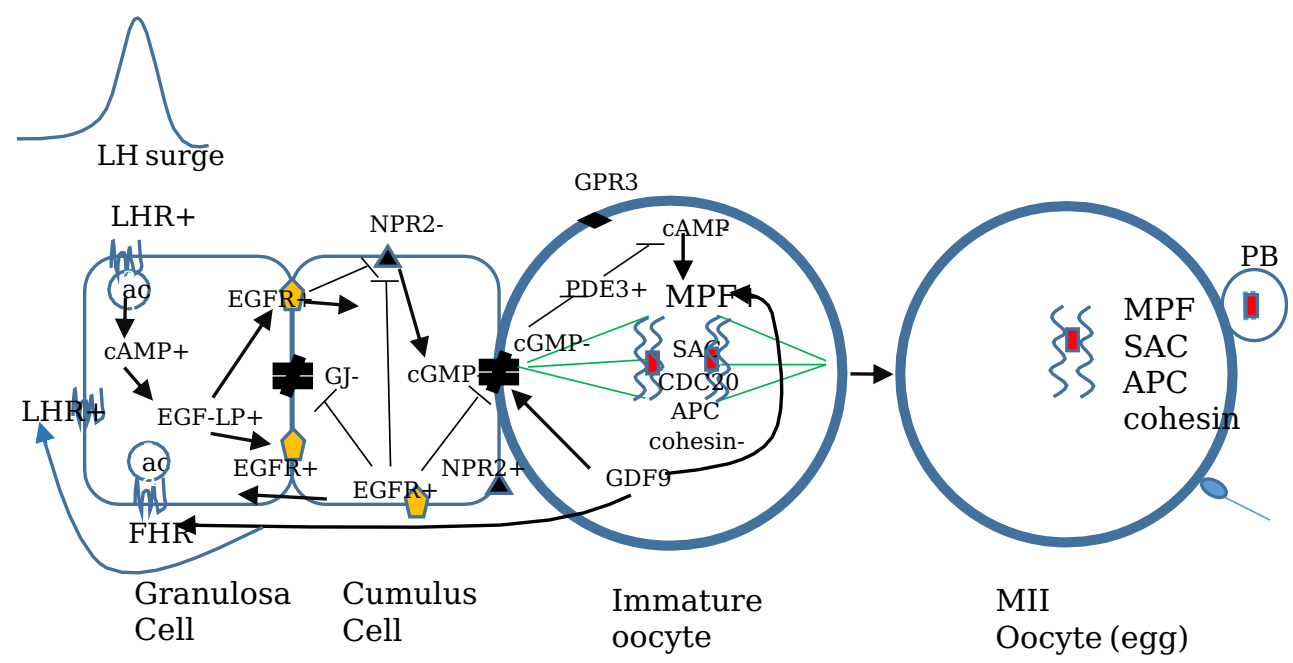

Fig. 2 Human model of LH regulation of oocyte meiotic maturation. The LH signal begins with mid-cycle LH activation of the mural granulosa cell LH receptor. The LH signal rapidly suppresses CNP/NPR2, activates the EGF/EGFR network, and inhibits gap junction activity. This reduces follicle and oocyte cGMP levels, activates oocytes phosphodiesterases, reduces oocyte cAMP levels, and activates the oocyte maturation promoting factor (MPF). The MPF initiates resumption of meiosis by protein phosphorylation of downstream proteins. The spindle assembly checkpoint (SAC) proteins are activated at the kinetochore to induce spindle formation and alignment. CDC20 activates the anaphasepromoting complex (APC) which initiates the transition from metaphase to anaphase by degrading securin releasing separase which degrades cohesin. This frees chromosomes to segregate to opposite poles. The first meiotic division is completed and the mature metaphase II oocyte remains arrested until fertilization. +, activation or stimulation; -, inhibition 
and EGF for 24, 48, and 72 h. MII oocytes were inseminated by ICSI; embryos were grown to days 5 and 6 . IVM cycles resulted in embryo transfers on day 6. CCs were collected from the GV-staged oocytes, mRNA was extracted, and RTPCR for LHR, FSH receptor, and EGF receptor was performed. The MII rate (Grp A-24h-70\%, 48h-80\%, 74h$85 \%$ ), blastocyst rate (A-40\%, B-23\%, C-23\%), and CC LH receptor mRNA expression levels were higher in group $\mathrm{A}$ than groups $\mathrm{B}$ and $\mathrm{C}$. The study concluded that oocytes from expanded/dispersed CCs with high CC LH receptor mRNA expression levels have better oocyte quality compared with oocytes from unexpanded CCs with low LHR mRNA levels.

Regan et al. studied LHR mRNA expression density in 327 ovarian follicles from young and old patients treated with IVF [29]. Granulosa cell LH receptor density was measured by immunofluorescence from GCs retrieved after standard controlled ovarian hyperstimulation. GC LHR density was increased in young women compared with older women. Higher live birth rates were found in young women with high GC LHR density compared with older women with lower GC LHR density. They also found that the LH surge-induced downregulation of the $\mathrm{LH}$ receptor was evident mostly in the larger follicles in young women. LHR downregulation was not observed in follicles from older women. This suggested to the authors that large follicles are more receptive to the LH surge than smaller follicles since they downregulated appropriately. This may indicate a GC dysfunction in small follicles and follicles in older women. Also, the FSH dose used for IVF stimulation was not associated with GC LHR expression levels which suggests that other factors other than gonadotropins regulate GC LHR expression during follicular development. The authors concluded that high GC LH receptor density and normal downregulation of the GC LH receptor by the LH surge which is primarily found in preovulatory dominant follicles are associated with oocyte quality.

Maman et al. found higher CC LHR mRNA expression in MII oocytes compared with MI and GV oocytes; however, higher LHR expression was not associated with higher fertilization rates [32]. Huang et al. found that LHR CC mRNA expression was not associated with a higher pregnancy rate [33]. Whether high or low LHR mRNA expression in CCs is associated with oocyte and embryo quality is not clear.

\section{Follicle C-natriuretic Peptide and Natriuretic Peptide Receptor 2}

The first target of the LH signal in the follicle compartment is the CNP/NPR2 system. LH suppresses the CNP/NPR2 system and within minutes reduces cGMP follicle levels. This ultimately leads to activation of the oocyte maturation promoting factor (MPF) which initiates resumption of meiosis and chromosome segregation. The CNP/NPR2 system is the major inhibitor of oocyte meiosis progression in the ovarian follicle. The first clue that ovarian follicle somatic cells express an inhibitor that prevents meiotic progression came when Pincus and Enzman in 1935 observed spontaneous oocyte maturation within $1-2 \mathrm{~h}$ in vitro at the time oocytes were separated from ovarian follicle somatic cells [164]. This phenomenon occurs in mouse, sheep, cow, pig, monkey, and human oocytes [165].

Initial studies suggested that the follicle factor responsible for oocyte meiotic arrest was cAMP [166-168]. Later studies showed that cAMP produced by the oocyte, not cAMP from the follicle, was the major inhibitor of oocyte meiotic arrest. Mehlmann et al. injected mouse oocytes with antibodies against stimulatory $G$ protein (Gs) which stimulates oocyte adenylyl cyclase and cAMP production. This caused resumption of meiosis, $80 \%$ of the injected oocytes developed GVBD showing that oocyte Gs is required for meiotic arrest [169]. Horner et al. showed that oocyte GPR3 activates oocyte adenylyl cyclase (AC3) which produces cAMP in the oocyte [170]. Later, Mehlmann et al. showed that the oocyte Gs is linked to the oocyte receptor $\mathrm{G}$ protein-coupled receptor 3 (GPR3) which is required for meiotic arrest in mice [171] and humans [78].

cGMP is the major factor in the follicle responsible for oocyte meiotic arrest [9]. Norris et al. found that reducing oocyte cGMP levels increased the activity of oocyte phosphodiesterase 3A (PDE3A) and lowered levels of oocyte cAMP which induced resumption of meiosis [172]. They also found that blocking follicle gap junctions reduced oocyte cGMP. They concluded that cGMP produced by ovarian follicle somatic cells enters the oocyte through gap junctions and inhibits PDE3A activity which allows high levels of cAMP to accumulate in the oocyte. High oocyte cAMP levels trigger resumption of meiosis. How is cGMP produced in the ovarian follicle compartment?

C-natriuretic peptide (CNP), also called natriuretic peptide precursor C (NPPC), and its receptor guanylyl cyclase natriuretic peptide receptor 2 (NPR2) produce cGMP in the ovarian follicle compartment. CNP and NPR2 are highly expressed and regulated in ovarian follicles during the rat estrus cycle [173]. In 2010, Zhang et al. showed that CNP mRNA expression was 10-fold higher in mural GCs compared with CCs, and NPR2 mRNA expression was 2-fold higher in CCs compared with mGCs [174]. CNP increased oocyte cGMP levels in the follicle which inhibited meiotic resumption. They also studied the role of oocyte-secreted factors (OSFs) on the follicular compartment. They found that bone morphogenetic peptide 15 (BMP15) combined with growth differentiation factor 9 (GDF9) increased CC NPR2 mRNA expression. This suggested that BMP15 and GDF9 primarily inhibit meiotic progression.

Based on these findings, the authors proposed a model for oocyte meiotic arrest. Mural GC CNP activates CC NPR2 
which increases cGMP production in the follicular compartment. Follicle cGMP diffuses through follicle/oocyte gap junctions into the oocyte. Oocyte cGMP inhibits oocyte PDE3A activity which increases oocyte cAMP. High oocyte cAMP levels inhibit resumption of meiosis. Genetic studies support this model. NPR2 mutant mice are infertile due to premature resumption of meiosis caused by a lack of follicle cell cGMP production which results in oocyte fragmentation and poor embryo development [175, 176]. Humans with NPR2 mutations develop acromesomelic dysplasia, Marateaux type (AMDM) [177]. Infertility has not been described in these patients.

LH exposure inhibits the CNP/NPR2 system which induces oocyte meiotic resumption in preovulatory follicles. $\mathrm{LH}$ reduces cGMP levels very rapidly in the mural $\mathrm{GC}, \mathrm{CC}$, and oocyte. Time-lapse recordings of cGMP levels in mouse follicles showed a decrease in cGMP levels in mural GCs within $1 \mathrm{~min}$ of $\mathrm{LH}$ exposure, in CC within $5 \mathrm{~min}$, and in oocytes within $10 \mathrm{~min}$ [178]. LH reduced NPR2 activity in mural GCs and CCs within $3 \mathrm{~h}$ of LH exposure by dephosphorylation, and NPR2 protein levels did not change. LH also reduced CNP levels within $2 \mathrm{~h}$ of LH exposure [17]. How the LH deactivates NPR2 is not clear. One possible mechanism is that LH activates EGF/EGFR which inhibits NPR2. EGF receptor was activated within $15 \mathrm{~min}$ after LH application [179] and resulted in reduced follicle cGMP levels [180].

In humans, the ovarian follicle CNP/NPR2 system has not been well studied. One paper showed that LH reduces CNP levels in human ovarian follicular fluid [16], and one paper found NPR2 mRNA expression in human mural GCs [34] (Fig. 2).

\section{Epidermal Growth Factor Network}

The second target of the LH signal is the ovarian follicle EGF network. The activated EGF network transmits the LH signal from the mural granulosa cells (mGCs) to the oocyte in preovulatory follicles. The activated EGF network inhibits the CNP/NPR2 system and gap junctions reducing follicle and oocyte cGMP. This occurs via the EGF receptor which is highly expressed in follicle cumulus cells. cGMP is the molecule that transmits the LH signal from the follicle to the oocyte.

EGF-like protein (EGF-LP) growth factors stimulate oocyte meiotic maturation and cumulus cell expansion [36, 181]. The first evidence that EGF regulates these processes came in the 1980s [182, 183]. Recently, Park et al. showed that $\mathrm{LH}$, within $3 \mathrm{~h}$, stimulates production of epidermal growth factor-like protein (EGF-LP) family members: amphiregulin (AREG), epiregulin (EPI), and beta-cellulin (BTC) in mice ovaries [184]. EGF-LP expression was restricted to mural GCs in preovulatory follicles. EGF-LP stimulated oocyte meiotic maturation within $4 \mathrm{~h}$ of exposure to AREG and EPI as GVBD was observed in $100 \%$ of the oocytes in preovulatory follicles. EGF-LP also stimulated cumulus cell expansion within 8 to $12 \mathrm{~h}$ of exposure to AREG, EPI, or BTC. Cumulus cell expansion genes were upregulated. Hyaluronan synthase 2 (HAS2), prostaglandin-endoperoxide synthase 2 (Ptgs2), and tumor necrosis factor alpha-induced protein 6 (Tnfaip) mRNA expression levels increased within $3 \mathrm{~h}$ of exposure to EPI, AREG, and BTC. LH stimulates production of AREG, EPI, and BTC via p38 mitogen-activated protein kinase (MAPK) $[185,186]$. In null AREG and EREG mice, meiotic resumption is reduced [187].

Activation of the EGF receptor (EGFR) is required for oocyte meiotic resumption [188] and cumulus cell expansion. EGF receptors are members of the tyrosine kinase receptor (TKR) family that includes ErbB1, ErbB2, ErbB3, and ErbB4 [189]. EGF tyrosine kinase receptors are single-transmembrane domain receptors that regulate cellular proliferation. EGF binding sites were first identified on rat GCs in secondary ovarian follicles in 1986 [190]. The highest EGFR mRNA expression levels are in CCs [181]. LH causes EGF receptor (EGFR) phosphorylation within $3 \mathrm{~h}$ of exposure [184]. EGFR activation is required for LH action. EGFR inhibitors block LHinduced oocyte meiotic resumption and $\mathrm{CC}$ expansion. EGFR signals via extracellular signal-regulated kinases 1 and 2 (ERK1/2) [191, 192]. Granulosa cell-specific EGFR null mice fail to resume meiosis [193].

The LH-activated EGF network targets the CNP/NPR2 system and follicle/oocyte gap junctions. The EGF network inhibits CNP/NPR2 production of cGMP and suppresses gap junction activity. LH-activated EGFR reduces CNP mRNA expression levels in granulosa cells [176], and cGMP levels in the follicle and oocyte. Reduced oocyte cGMP levels activate oocyte PDE which reduces oocyte cAMP levels. This activates the oocyte maturation promoting factor (MPF) which initiates resumption of meiosis [180, 194].

The EGF system is found in the human follicle [36]. The human primordial follicle does not express EGF or EGFR [37]. Maximum EGF and EGFR expression occurs in preovulatory follicles [38]. EGF is expressed in human preovulatory follicle follicular fluid (FF) [39]. Reeka et al. failed to detect EGF in human FF, but found EGF in GCs [40]. Zamah et al. found EGFR mRNA expression in human GCs from IVF patients [35].

LH increases production of EGF-LP in human GCs and CCs (Fig. 2) [41, 42]. AREG mRNA and protein are expressed in human GCs [41]. AREG is the most abundant EGF-like growth factor in follicular fluid aspirated at oocyte retrieval in IVF patients stimulated with gonadotropins. Rimon et al. reported a 286-fold increase in AREG expression in GC from IVF patients [43]. Whether EGF-LP suppresses CNP/NPR2 and inhibits gap junctions resulting in oocyte 
meiotic resumption is not known. One study found that LH reduces CNP levels in human FF [35].

Mixed results have been found in studies investigating the association between EGF molecules and oocyte quality. Feuerstein et al. found a positive correlation between CC AREG mRNA expression and blastocyst rate [44]. Huang et al. found that high CC AREG mRNA expression from MII oocytes was associated with pregnancy rate [33]. Zamah et al. found that AREG levels from FF correlated with oocyte maturation rate [35]. Hoffman et al. found that human EGF FF levels were inversely correlated with oocyte maturation [45]. Inoue et al. found that FF AREG levels were inversely correlated to fertilization rate and was not correlated with embryo quality [46]. A reliable EGF network oocyte quality biomarker has not been identified.

\section{Gap Junction Communication}

The third major target of the LH signal is the follicle/oocyte gap junction. Gap junction channels allow direct communication between cells. They allow ions and molecules to pass from the cytoplasm of one cell to the cytoplasm of the other, thereby coupling the cells metabolically and electrically. Studies have demonstrated that small fluorescent dye molecules injected into one cell can pass into adjacent cells, provided the molecules are smaller than $1000 \mathrm{Da}$. This suggests a gap junction channel diameter of $1.5 \mathrm{~nm}$ so cells can share small molecules like ions, nucleotides, and amino acids, but not large molecules like proteins or nucleic acids. The molecular mass of cGMP is 345.2 and cAMP $507 \mathrm{Da}$. Gap junctions are formed from connexons which are formed from connexins. Several distinct connexins have been identified. Connexins are named by their molecular weights. Connexin 43 has a molecular weight of $43 \mathrm{kDa}$. Gap junction channels behave like conventional gated ion channels. They flip between open and closed states, switching rapidly within seconds. Gap junctions regulate hearing, cardiac and neural function, liver function, and ovarian folliculogenesis and oogenesis $[195,196]$.

Gap junctions are present between mural granulosa cells and cumulus cells [166], and between cumulus cells and oocytes [197]. Connexins are expressed in ovarian follicles [198, 199]. Connexin 43 and 37 are the primary functional connexins in the ovarian follicle. $\mathrm{Cx} 43$ is the major connexin expressed in rat granulosa/cumulus cells [200]. Cx37 is primarily expressed in the oocyte [201]. Gap junctions regulate meiotic arrest and resumption [198]. CNP/NPR2 produces cGMP in cumulus cells which diffuses into oocytes through Cx43 gap junctions which elevates oocyte cGMP. This maintains oocyte meiotic arrest [202].

LH disrupts gap junction (GJ) communication between the follicle somatic cells and oocyte which induces resumption of meiosis. Initial gap junction studies found that loss of CC gap junctions induced GVBD in rat oocytes [203, 204]. LH closes follicle GJs [205, 206] and oocyte GJs [207]. LH inhibits rat gap junction activity via MAPK phosphorylation [207] of Cx43 and also reduces $\mathrm{Cx} 43$ protein levels [208]. The activated EGF network also closes cumulus cell and oocyte gap junctions [180]. AREG activates EGF receptor which closes follicle gap junctions. This prevents transport of cGMP from the follicle somatic cells to the oocyte which induces resumption of meiosis [172]. In porcine IVM conditions, LH closes connexin 43 gap junctions [209]. Mice lacking connexin 37 lack mature Graafian follicles, and the oocytes are arrested at the early antral stage, fail to grow, fail to ovulate, and develop inappropriate corpus lutea [210, 211].

Gap junctions regulate human ovarian folliculogenesis (Fig. 2) [47]. Human ovarian follicles express 15 connexins, but only Cx43 and Cx37 form gap junctions [48, 49]. Cx43 is the major gap junction connexin in human cumulus cells [49]. Human gap junctions are regulated by cAMP [50]. BMP15 reduces $\mathrm{Cx} 43$ expression and gap junction activity in human granulosa cell lines and granulosa cells [51]. Whether LH closes human follicle/oocyte gap junction activity is not known. We found no studies addressing this question.

Cumulus cell mRNA expression studies suggest $\mathrm{Cx} 43$ may be a potential biomarker of human oocyte quality. Feuerstein et al. found that $\mathrm{Cx} 43$ was associated with improved oocyte quality [52]. Wang et al. found higher live birth rates in oocytes with high CC Cx43 mRNA levels [49]. Low CC Cx43 expression was found in low responders [53]. Reduced expression of $\mathrm{Cx} 43$ at oocyte retrieval was associated with improved oocyte quality [54]. Double trigger with GnRH agonist and HCG reduced Cx43 mRNA CC expression and improved oocyte and embryo quality [55]. It is not clear whether increased or decreased $\mathrm{Cx} 43 \mathrm{CC}$ mRNA 43 expression is associated with oocyte quality.

\section{Oocyte-Secreted Growth Factors: BMP15 and GDF9}

The major oocyte-secreted growth factors studied so far are BMP15 and GDF9. Whether oocyte BMP15 and GDF9 are targets of the LH signal during oocyte meiotic maturation in animals or humans is not known. It is well established that pituitary gonadotropins regulate ovarian folliculogenesis and oocyte quality $[212,213]$. Recent work suggests that the oocyte regulates folliculogenesis [214-219] and oocyte quality $[220,221]$. Oocyte-secreted factors (OSFs), bone morphogenetic protein 15 (BMP15) and growth differentiation factor 9 (GDF9), are important regulators of ovarian follicle development [222, 223]. They are exclusively expressed in the oocyte, are present in all stages of follicular growth [224], and may have a role in human oocyte maturation. Recently, other OSFs 
have been identified. Oocyte interleukin-7 (IL-7) was found to possibly have a role in human oocyte maturation [225].

BMP15 and GDF9 regulate animal and human ovarian folliculogenesis. Initial studies, 50 years ago, found that premature luteinization of the rabbit ovarian follicle occurs when the oocyte is removed from the follicle. This suggested that an oocyte-secreted factor (OSF) prevents luteinization. The authors proposed the concept that the oocyte controls follicle somatic cell processes [226]. Mouse genetic studies showed that GDF9 is required for normal ovarian follicle development [227]. GDF9 null mice ovarian follicles do not progress beyond the primary follicle stage, which results in infertility. During the last decade, studies in animals showed that GDF9 and BMP15 are involved in cumulus cell expansion $[228,229]$ and oocyte quality $[72,221,230]$.

BMP15 and GDF9 are members of the transforming growth factor-beta (TGF- $\beta$ ) superfamily, a structurally conserved group of proteins with at least 35 members [231]. The members of the superfamily are classified into subfamilies. They include the TGF- $\beta$ subfamily (TGF- $\beta 1-\beta 3$ ); the bone morphogenetic (BMP) subfamily is the largest with 20 members, the growth differentiation factor (GDF) subfamily with 9 members, the activin/ inhibin subfamily, the glial cell-derived neurotrophic factor (GDNF) subfamily, and anti-Mullerian hormone. GDF9 was initially discovered in 1993 [232]. The TGF- $\beta$ superfamily is composed of growth factors that regulate reproduction, embryo development, and tumor growth [233].

The TGF- $\beta$ superfamily members act by binding two types of serine/threonine kinase cell surface receptors called types I and II. Seven type I and five type II receptors have been identified. BMP15 and GDF9 bind several receptors including the serine/threonine kinase receptor type II bone morphogenetic receptor type-2 (BMPR2) [234], bone morphogenetic receptor type-IB (BMPR1B) also known as activin receptorlike kinase (ALK6) and bone morphogenetic receptor type-IA (BMPR1A) also known as ALK3. BMP15 and GDF9 primarily bind BMPR1B which is the major TGF- $\beta$ receptor in ovarian follicles [58, 222, 235, 236]. GDF9 and BMP15 signal through SMAD transcription factors (fusion of Caenorhabditis elegans Sma genes and the Drosophila Mad, Mothers against decapentaplegic) [237] to regulate granulosa cell function in animals and humans [58].

\section{GDF9}

Growth differentiation factor 9 (GDF9) is an oocyte-derived growth factor [238] required for folliculogenesis and oogenesis. It is a protein in the TGF $\beta$ superfamily, composed of 454 amino acids with a molecular weight of $53.4 \mathrm{kDa}$. GDF9 controls follicle growth by stimulating ovarian follicle granulosa cell proliferation at all stages of follicle development $[239,240]$. It stimulates granulosa cell proliferation [241] by both increasing GC FSH receptor expression [242] and preventing GC apoptosis [243].

GDF9 is required for oogenesis. GDF9 null mice are infertile due to severe follicle and oocyte abnormalities [227]. The ovaries are small, and primordial and primary follicles never develop more than only 1 layer of granulosa cells. Follicular development never progresses beyond this early stage. The ability of the granulosa cells to proliferate is severely limited. The primary follicle oocytes are enlarged $(70-\mu \mathrm{m}$ diameter); they resemble antral follicle oocytes. Electron microscopy oocyte studies found perinuclear organelle aggregation, abnormal Golgi complexes, and failure to form cortical granules [244]. This study demonstrated for the first time that the oocyte controls the progression of follicular development.

GDF9 promotes cumulus cell expansion during preovulatory follicle development. LH stimulates CC expansion which is essential for the acquisition of oocyte quality [221]. The factors that control CC expansion are still not known. GDF9 regulates numerous $\mathrm{CC}$ functions that are involved in CC expansion [245]. GDF9 induces CC expansion genes including pentraxin (Ptx3), hyaluronan synthase 2 (Has2), tumor necrosis factor alpha-induced protein 6 (Tnfaip6), and prostaglandin-endoperoxide synthase 2 (Ptgs2) [246]. GDF9 also inhibits granulosa cell LH receptor mRNA expression [246]. RNA interference studies in mice decrease oocyte GDF9 protein expression, prevent $\mathrm{CC}$ expansion, and reduce Has2 and Pgs 2 mRNA expression [247]. In addition, GDF9 regulates CC cholesterol biosynthesis [248] and glycolysis [249] which is required to support the metabolic activity during CC expansion. SMAD mice knockouts demonstrate that SMAD 2, 3 , and 4 are required for $C C$ expansion [250, 251]. Recent studies suggest that BMP15:GDF9 mouse and human heterodimers are potent regulators of CC expansion [252]. These studies support the hypothesis that GDF9 regulates $\mathrm{CC}$ expansion.

The role of GDF9 in human folliculogenesis, cumulus cell expansion, and oocyte meiotic maturation is not clear. GDF9 is expressed in human oocytes [25, 61, 62]. Aaltonen et al. studied GDF9 expression in ovarian biopsies from women under the age of 35 [61]. They found GDF9 mRNA expression in primary oocytes. Primordial oocytes did not express GDF9. Because they did not find antral follicles or preovulatory follicles in their biopsy specimens, they were not able to study GDF9 in these later stages. GDF9 stimulates human granulosa cell (GC) proliferation [63, 64]. GDF9 stimulates activin signaling [62] and inhibits follistatin [65] in preovulatory luteinized GC from women undergoing IVF. GDF8 downregulates Ptx 3 , a cumulus cell expansion gene, in human GC $[66,67]$. Huang et al. reported the first human study on GDF9 regulation of human-luteinized GC cycle progression [68]. GDF9 upregulates both cyclin D1 and E mRNA and protein via ERK42/44 and SMAD3. 
Human genetic studies suggest that GDF9 regulates human folliculogenesis and oocyte development. GDF9 mutations cause premature ovarian insufficiency (POI). Seven GDF9 human mutations have been identified that cause POI [253-256]. GDF9 mutations may cause diminished ovarian reserve [256]. Oocyte GDF9 expression is reduced in PCOS patients [69-71]. This suggests that low GDF9 expression may block antral follicle development, the main follicle abnormality found in PCOS.

GDF9 targets including HAS2, TNFA1P6, PTGS2, and gremlin 1 are potential biomarkers of oocyte quality [246, 257, 258]. In humans, CC HAS2, PTGS2, and gremlin mRNA expression correlates with oocyte quality [259, 260]. Feuerstein et al. found that CC PTGS mRNA is associated with oocyte maturation [44]. Gode et al. found that increased FF GDF9 protein levels correlated with improved oocyte maturation and embryo quality [261]. These studies suggest that CC expansion genes and GDF9 in FF are associated with oocyte quality.

The GDF9 receptor, BMPRII, is also a potential biomarker of oocyte quality. Regan et al. studied granulosa cell BMPR1B mRNA density in young and old women treated with IVF [29]. In young women, no correlation was found between GC BMPR1B density and GC LHR density $\left(R^{2}=.078\right)$; as expected, GC BMPPR1B density did not increase and was downregulated, as LHR density increased. In older women, BMPR1B density increased as LHR density increased $\left(R^{2}=0.87 ; p=0.004\right)$. The authors concluded that normal downregulation of GC BMPR1B is associated with oocyte quality.

\section{BMP15}

Bone morphogenetic protein (BMP15) is a 392-amino acid dimeric protein in the TGF- $\beta$ super family, exclusively expressed in the oocyte. BMP15 is expressed in the oocyte throughout follicular development. It binds granulosa cell TGF- $\beta$ receptors and activates SMAD transcription factors that regulate gene expression. BMP15 stimulates folliculogenesis, cumulus cell expansion, oogenesis, and oocyte maturation and controls ovulation number and oocyte developmental competence. BMP15 human mutations cause ovarian dysgenesis and premature ovarian failure.

BMP15 stimulates proliferation of ovarian follicle GCs [236, 242, 262], stimulates cumulus cell expansion [230, 263], and inhibits ovarian follicle steroidogenesis. In mice, BMP15 regulates CC expansion via SMAD 2/3 stimulation of gene transcription [250,264,265], stimulation of CC EGFR expression [266], and inhibition of CC apoptosis [267].

BMP15 promotes oocyte meiotic arrest by increasing follicle cGMP levels by increasing follicle CNP/NPR2 activity, by increasing NPR2 gene expression [268], and by modulating gap junction activity [51]. In preovulatory follicles,
BMP15 inhibits FSH receptor expression and reduces progesterone and estrogen production [269].

Sheep with homozygous BMP15 mutations [270] are infertile and develop streak gonads, and folliculogenesis is blocked at the primary follicle stage [271, 272]. Ovulation rates are increased in sheep with heterozygous BMP15 mutations [270].

The role of BMPs in human folliculogenesis and oogenesis is still unclear [273]. Human ovarian follicles express BMPs and BMP receptors. BMP15 protein and mRNA are expressed in oocytes and granulosa cells in fetuses and young women [73]. BMP6 and BMP15 are the most highly expressed BMPs in pre-antral human follicles. GDF9, BMPR2, and SMAD3-4 are also expressed in human pre-antral follicles [56]. BMP2, BMP4, BMP7, BMP15, GDF8, and GDF9 are present in human pre-antral follicle follicular fluid (FF). BMP4, BMP5, BMP6, BMP7, and BMP8 are also expressed in human GCs [74]. BMPRII is the most highly expressed type II receptor in cumulus cells [57]. ALK1 through ALK7 are also expressed primarily in pre-antral and antral follicles [56].

How BMP15 regulates ovarian folliculogenesis and oocyte maturation in humans remains unclear. BMP15 suppresses ovarian follicle steroidogenesis and gap junction activity. BMP15 prevents luteinization by suppressing GC progesterone production. BMP15 and GDF9 decrease GC progesterone production by inhibiting StAR expression [75, 76]. BMP15, BMP7, and BMP4 regulate $\mathrm{Cx} 43$ expression $[51,274]$. cAMP enhances BMP15-regulated SMAD 1/5/8 signaling in human granulosa cells, suggesting communication between the follicle cAMP system and BMP15/SMAD [59]. BMP15 and GDF9 augment FSH/cAMP stimulation of aromatase mRNA expression in human cumulus cells via SMAD 2/3 [60].

Human BMP15 mutations were first reported in 2004 in two Italian sisters with premature ovarian insufficiency (POI), ovarian dysgenesis, and a granulosa cell proliferation deficiency [275]. Over 1236 cases of POI associated with BMP15 mutations have been described. The risk of a BMP15 mutation is $10 \times$ higher in POI patients [276].

BMP15 is a potential biomarker of human oocyte quality. Higher oocyte maturation rates were found in oocytes from follicles with high BMP15 follicular fluid (FF) levels [77, 277]. In IVF poor responders, high BMP15 FF levels are associated with higher fertilization rates, cleavage rate, and good-quality blastocyst compared with low BMP15 FF levels [77]. Li et al. studied 196 infertile women and 2426 COCs. Increased BMP15 and GDF9 mRNA levels in CC correlated with oocyte maturation, fertilization, and embryo quality [72]. Higher oocyte quality was found in oocytes from follicles with high cumulus cell BMP2 expression levels [278]. Dysregulation of activin receptor-like kinase 6 (ALK6) in human GCs is correlated with decreased ovarian reserve [28]. A BMP15 single nucleotide polymorphism is associated with ovarian hyperstimulation [279]. 


\section{Oocyte Maturation Promoting Factor: Cyclin-Dependent Kinase 1 and Cyclin B1}

The major target of the LH signal in the oocyte is the maturation promoting factor (MPF). The activated MPF initiates resumption of meiosis in the preovulatory follicle. The MPF complex has two components, a cyclin-dependent protein kinase1 (CDK1), also known as cell division cycle protein 2 (Cdc2), and cyclin B [280]. The MPF acts by phosphorylating downstream proteins. Three of the major systems are the SAC proteins, $\mathrm{APC} / \mathrm{C}$, and the securing-separase/cohesin proteins. These cell cycle control proteins first appeared 1 billion years ago and have been conserved in all eukaryotic species from yeast to humans. The same cell cycle mechanisms that operate in yeast and invertebrates also operate in humans. Phosphorylation of these proteins by CDK1 induces cell cycle progression and completion of the first and second meiotic divisions. The MPF and the other components of the cell cycle machinery are not well characterized in human oocytes.

The MPF controls both the mitotic and meiotic cell cycles. The cell cycle is the fundamental way by which cells grow and divide. The cell cycle is divided into four distinct phases: $\mathrm{M}$ phase, G1 phase, S phase, and G2 phase. During the M phase, the cell divides by mitosis and cytokinesis. The G1 phase is the gap between the $\mathrm{M}$ phase and $\mathrm{S}$ phase. During the $\mathrm{S}$ phase, the DNA replicates. The G2 phase is the gap between the $\mathrm{S}$ phase and $\mathrm{M}$ phase. The interphase is the period between one $M$ phase and the next $M$ phase. During interphase, the cell grows continuously. The duration of the $\mathrm{M}$ phase in an average eukaryotic cell is $1 \mathrm{~h}$. The average cell cycle duration is $24 \mathrm{~h}$. The early embryonic cell cycle duration in preimplantation human embryos is $12-24 \mathrm{~h}$. The cell cycle is controlled by a biochemical machine composed of proteins that duplicate and divide the cell and its contents.

The MPF was purified from Xenopus eggs [281,282] and starfish oocytes [283]. The human CDK1 cDNA [284] and protein sequence [285] were subsequently identified. CDK1 is composed of 297 amino acids. The molecular weight is $34 \mathrm{kDa}$. The crystal structure of CDK1 was recently reported [286]. CDK1 is a serine/threonine-specific kinase activated by a cyclin partner. The CDK family is composed of 20 proteins divided into two major groups: cell cycle (CDK1, 2, 3, 4, 6, 5, 14, 15, 16, 17, 18) and transcriptional $[7-13,19,20$, and]. The cyclin family is composed of 30 proteins $[287,288]$. CDK1 controls the cell cycle. Seventyfive targets of CDK1 have been identified that regulate many aspects of the mitotic cell cycle, including DNA replication and segregation, cell differentiation, cell polarity and morphology, genome stability, transcription, and metabolism [289]. CDK1 also regulates meiosis.

High oocyte cAMP levels prevent resumption of oocyte meiosis. High oocyte cAMP levels are maintained by constitutively active oocyte GPR3 receptors [8] and low oocyte phosphodiesterase (PGE3A) activity maintained by high oocyte cGMP levels which prevents hydrolysis of cAMP to AMP [290]. The phosphodiesterase (PDE) superfamily is composed of 11 PGE gene families [291]. PDE3A is highly expressed in mouse oocytes [292]. Resumption of meiosis is blocked in PDE3A knockout mice [293]. Mehlmann et al. found that oocyte $\mathrm{G}$ protein-coupled receptor 3 (GPR3) and GPR12 activate oocyte adenylate cyclase which increases cAMP [169]. GPR3 is essential for meiotic arrest in mice. GPR3 is expressed 14-fold higher in the oocyte compared with follicular somatic cells. GPR3 knockout mice undergo spontaneous oocyte nuclear maturation [171], and mice lacking adenylyl cyclase-AC3 spontaneously resume meiosis progression [170].

High oocyte cAMP levels inhibit the MPF via activation of oocyte phosphatases. The major MPF oocyte phosphatase inhibitors are WEE1B, CDC25, and CDC14A [11, 294]. CDC25A and CDC25B phosphatases inactivate Cdk1/ Cyclin B, which maintains oocyte meiosis arrest in mice [295-297]. CDC14A phosphatase also inhibits CDK1 [298]. In vivo knockdown of WEE1B induces spontaneous resumption of meiosis [299, 300].

The LH signal activates the MPF [301]. LH reduces follicular oocyte GMP levels which activates oocyte PDE3A. This in turn reduces oocyte cAMP levels. Low oocyte cAMP levels inactivate oocyte phosphatases, WEE1B and CDC25 [302, 303], which dephosphorylate and activate oocyte CDK1 [18]. The activated CDK1-cyclin B complex phosphorylates many downstream substrates including spindle assembly checkpoint (SAC) proteins localized at chromosome kinetochores [304]. The primary SAC proteins include Mad1, Mad2, Bub1, BubR1, Bub3, Mps1, and aurora B/C kinase. The main function of SAC proteins is to assure that each phase of the cell cycle is completed prior to progressing to the next phase, and to guide microtubule spindle attachment to the kinetochores [305, 306]. SAC protein function is well studied in mitosis while in meiosis their functions are less clear [307].

The primary target of the SAC is the anaphase-promoting complex/cyclosome (APC/C) [308]. The APC/C is an ubiquitin ligase that adds ubiquitins on target proteins which are recognized and degraded by the proteasome. SAC proteins Mad1, Mad2, and BubR1 inhibit the APC/C. SAC proteins inhibit the APC/C from targeting securin (anaphase inhibitor) and cyclin $\mathrm{B}$ [304], thereby preventing resumption of meiosis. The activated APC/C-Cdc20 induces entry into anaphase and chromosome segregation [307]. Separase is inactive when bound to securin. At anaphase, the APC/C activated by Cdc20 cleaves securin (anaphase inhibitor) which activates separase. Activated separase cleaves the cohesin complex subunits which induces chromosome segregation.

In humans, the oocyte MPF complex is not well characterized [309]. CDK1 [25, 79, 80], CDC25 [25, 84], and WEE2 are expressed in human oocytes [80]. Sang et al. found WEE2 
mutations in four women with fertilization failure [83]. The age of the patients ranged from 27 to 37 , the mean number of oocytes retrieved per IVF cycle was 9, and the mean oocyte maturation rate was $70 \%$. All MII oocytes inseminated by ICSI failed to fertilize. Sanger sequencing identified WEE2 mutations in all 4 women.

SAC proteins including Bub1B, Bub3, AURKA $[25,80$, 82, 85-87], securin [82], and separase [88] are expressed in human oocytes. Cohesin is a multi-subunit protein complex made of four subunits. Four cohesin subunits are expressed in fetal [89] and adult human oocytes [90]: SMC1 $\beta$, SMC3, REC8, STAG3. Tsutsumi et al. found an age-related decrease of REC8 and SMC1 $\beta$ protein in prophase I-arrested oocytes in women. This suggests that a decrease in oocyte cohesin levels may cause human oocyte aneuploidy [91, 92]. STAG3 mutations may cause POI [310].

\section{Oocyte Quality and IVM}

One of the main clinical challenges facing assisted reproductive technology (ART) practitioners is the ability to select developmentally competent eggs and viable embryos [311]. The major problem is the unknown nature of oocyte competence also referred to as oocyte quality. Oocyte quality is defined as the ability of the oocyte to achieve meiotic and cytoplasmic maturation, fertilize, cleave, form a blastocyst, implant, and develop an embryo to term [312]. A major task for oocyte biologists is to find the oocyte mechanisms that control oocyte competence. Oocyte competence is acquired before and after the LH surge (Fig. 1). The development of oocyte competence requires successful completion of nuclear and cytoplasmic maturation [21]. Nuclear maturation is defined by cell cycle progression and is easily identified by microscopic visualization of the metaphase II oocyte. The definition of cytoplasmic maturation is not clear [5]. What are the oocyte nuclear and cytoplasmic cellular processes responsible for the acquisition of oocyte competence? What are the oocyte genes and how many control oocyte competence? Does LH signaling regulate oocyte competence? Can oocyte competence be improved?

Developmentally competent oocytes are able to support subsequent embryo development (Fig. 1). Oocytes progressively acquire competence during oogenesis. Several key oocyte nuclear and cytoplasmic processes regulate oocyte competence. The primary factor responsible for oocyte competence is probably oocyte ploidy and an intact oocyte genome. A mature oocyte must successfully complete two cellular divisions to become a mature healthy oocyte. During these cellular divisions, a high percentage of human oocyte chromosomes segregate abnormally resulting in chromosome aneuploidy. Oocyte aneuploidy is probably the major cause of reduced oocyte quality. Human oocytes are prone to aneuploidy. Over $25 \%$ of human oocytes are aneuploid compared with rodents $1 / 200$, flies $1 / 2000$, and worms $1 / 100,000$. Many human blastocysts are aneuploid [313]. The major cause of human oocyte aneuploidy is chromosome nondisjunction [309, 314-317].

Approximately $40 \%$ of euploid embryos are not viable. This suggests that factors other than oocyte ploidy regulate oocyte competence. Other key oocyte nuclear processes include oocyte cell cycle mechanisms, oocyte spindle formation [305, 318], oocyte epigenetic mechanisms [319], oocyte DNA repair mechanisms, and oocyte meiotic maturation [12, 312]. Oocyte cytoplasmic processes include oocyte cytoplasmic maturation [5, 320], bidirectional communication between the oocyte and cumulus cells [101, 221, 321], oocyte mitochondria, oocyte maternal mRNA translation [322, 323], and oocyte biomechanical properties [81]. During the last 10 years, human oocyte gene expression studies have identified genes that regulate oocyte competence.

Microarray studies of human oocytes suggest that over 10,000 genes are expressed in MII oocytes [324, 325]. In an early microarray study, Bermudez et al. found 1361 genes expressed per oocyte in five MII-discarded oocytes that failed to fertilize [326]. These genes are involved in many oocyte cellular processes: cell cycle, cytoskeleton, secretory, kinases, membrane receptors, ion channels, mitochondria, structural nuclear proteins, phosphatases, protein synthesis, signaling pathways, DNA chromatin, RNA transcription, and apoptosis. Kocabas et al. found over 12,000 genes expressed in surplus human MII oocytes retrieved during IVF from three women [327].

Jones et al. studied human in vivo matured GV, MI, and MII oocytes and in vitro matured MII oocytes collected from patients undergoing ovarian stimulation and IVF [328]. Oocyte RNA was extracted and loaded on genome microarrays. They found an increase in gene expression in immature oocytes (GV, 10,962; MI, 12,329) and in vitro mature MII oocytes (9479) compared with in vivo matured MII oocytes (7546). In addition, 2000 transcripts were expressed 2-fold higher in IVM MII oocytes compared with in vivo matured MII oocytes. These genes are involved in oocyte cellular processes including DNA transcription, cell cycle control, cellular protein metabolism, and signal transduction. The authors suggest that increased gene expression in immature GV and IVM oocytes is due to a dysregulation of oocyte gene transcription which may reduce oocyte competence.

Zeng et al. studied the molecular basis of oocyte competence by comparing gene expression profiles of low competent, moderate competent, and high competent oocytes. They compared the gene expression profiles of oocytes from nonstimulated rhesus female monkeys $(0.5-2-\mathrm{mm}$ follicles; low competence), in vitro matured oocytes from females stimulated with FSH (moderate competence), and in vivo matured oocytes from female monkeys stimulated with FSH and 
HCG (3-7-mm follicles; high competence) and compared subsequent embryo development in these groups [329]. mRNA expression levels of 23 genes expressed in oocytes and embryos were analyzed with RT-PCR. The major finding was an increase in oocyte mRNAs in non-stimulated oocytes. The authors suggest a failure in normal transcriptional silencing in the oocytes from small $<2.0-\mathrm{mm}$ follicles [330]. The embryos that developed from these low competent oocytes showed abnormally reduced gene expression. The authors conclude that altered transcription in non-stimulated oocytes from small follicles disrupts oocyte gene regulation, epigenetic modification, and metabolism. These oocyte abnormalities result in embryo developmental failure.

Grondahl et al. studied mRNA from normal donated MII oocytes from younger (<36 years) and older [113-115] women using whole-genome sequence microarray [88]. A total of 7470 genes/single MII oocyte were identified. They identified several major functional gene categories including cell cycle, meiosis and mitosis, spindle function, anaphase-promoting complex (APC), electron transport chain-mitochondria, and oxidative stress. A total of 342 genes were differentially expressed and greater than 2-fold expression was found in 103 genes. These genes included the following: cell cycle (SMAD2, MAPK4, CDKNIC), meiosis (separase, EMEI), spindle function (MAD2LI, DOCR1), anaphase-promoting complex (ubiquilin I, ANAPC4, UBE4B, USP2, USP34, USP42, USP9X), mitochondrial (mitochondrial fission regulator 1-MtfrI), and DNA repair (nuclear autoantigenic sperm protein-NASP). These genes may contribute to the ageassociated reduction in oocyte competence.

Grondahl et al. compared molecular pathways involved in oogenesis in oocyte from human primordial follicles and MII oocytes [82]. A total of 10,419 total genes and 2228 differentially expressed genes were identified in MII oocytes. The primary molecular pathways represented in MII oocytes showing 10-fold higher expression included cell cycle, oocyte maturation, and spindle organization, e.g., securin, cyclin B1, separase, CDC20, aurora kinase (AURKC), BMP15, GDF9, EGF, and EGFR. The authors state that accumulation of these specific transcripts in MII oocytes during oogenesis suggests that these genes may be important for MII oocytes to function. These genes may be required for the development of oocyte competence.

Riris et al. studied single human MII and GV oocyte mRNA levels of genes known to be functionally important contributors to oocyte quality in mice [80]. MII oocytes that failed to fertilize were studied. Ten genes were identified: CDK1, WEE2, AURKA, AURKC, MAP2k1, BUB1, BUB1B, CHEK1, MOS, FYN. mRNA levels were overall higher in GV oocytes than the MII oocytes. Individual MII oocyte mRNA abundance levels varied between patients. And gene expression levels widely varied among individual cell cycle genes in single oocytes.
WEE2 was the highest expressed gene of this group. BUB1 expression was the lowest, approximately 100fold lower than WEE2. Age-related changes were also observed. AURKA, BUB1B, and CHEK1 were lower in oocytes from an older patient than oocytes from a younger patient. The expression and abundance of these transcripts may reflect the level of oocyte competence.

Yanez et al. studied the mechanical properties, gene expression profiles, and blastocyst rate of 22 zygotes [81]. Mechanical properties at the zygote stage predicted blastocyst formation with $90 \%$ precision. Embryos that became blastocyst were defined as viable embryos. Single-cell RNA sequencing was performed at the zygote stage on viable and non-viable embryos. They found expression of 12,342 genes, of which 1879 were differentially expressed between both groups. Gene ontology clustering on the differentially expressed genes identified 19 functional clusters involved in oocyte cytoplasmic and nuclear maturation. At the zygote stage, all mRNAs, proteins, and cytoplasmic contents originate from the oocyte. The first two embryo divisions are controlled by maternal genes [331]. Gene deficiencies in cell cycle, spindle assembly checkpoint, anaphase-promoting complex, and DNA repair genes were identified in non-viable zygotes. Non-viable embryos had reduced mRNA expression levels of CDK1, CDC25B, cyclins, BUB1, BUB1B, BUB3, MAD2L1, securin, ANAPCI, ANAPC4, ANAPC11, cohesion complex genes including SMC2, SMC3 and SMC4, BRCA1, TERF1, ERCC1, XRCC6, XAB2, RPA1, and MRE11A. The authors suggest that reduced cell cycle transcript levels may explain abnormal cell division in cleavage embryos and blastocyst, and embryo aneuploidy.

Reyes et al. studied molecular responses in 10 oocytes $(5$ $\mathrm{GV}, 5 \mathrm{MII}$ ) from young women and 10 oocytes (5 GV, $5 \mathrm{MII}$ ) from older women using RNA-Seq sequencing (HiSeq 2500; Illumina) [79]. Patients were stimulated with FSH and triggered with HCG. GV oocytes were collected and used in this study. Some GV oocytes were placed in IVM media supplemented with FSH, EGF, and BMP. MII oocyte and GV oocyte total RNA was extracted, cDNA was synthesized and amplified and sequenced by single-cell RNA-Seq. Expressed genes were analyzed using weighted gene correlation network analysis (WGCNA). This identifies clusters of correlated genes. They found 12,770 genes expressed per oocyte, transcript abundance was greater in GV than MII oocytes, 249 (2\%) were specific to MII oocytes, and 255 genes were differentially expressed between young and old MII oocytes. The major age-specific differentially expressed gene functional categories identified were cell cycle (CDK1), cytoskeleton, and mitochondrial (COQ3).

These human oocyte studies suggest that oocyte cell cycle genes are key regulators of oocyte competence. Cell cycle genes may be expressed 10-fold higher in MII oocytes compared with immature oocytes. These include securin, cyclin 
B1, separase, CDC20, aurora kinase (AURKC), BMP15, GDF9, EGF, and EGFR. The accumulation of these specific transcripts in MII oocytes during oogenesis suggests that these cell cycle genes may be required for the development of oocyte competence. Cell cycle gene expression levels are variable between MII oocytes. Not all MII oocytes are competent. A unique cell cycle gene expression profile may indicate MII oocyte competence. Cell cycle gene expression levels are reduced in abnormal blastocyst. These human oocyte studies suggest that cell cycle genes (Table 1) are required for the acquisition of oocyte competence, and that MII oocytes with abnormal cell cycle gene expression profiles develop abnormal embryos. Understanding the molecular determinants of oocyte quality is clinically important. The dramatic reduction of oocyte quality associated with advancing maternal age is a major cause of infertility [332]. Currently, there is no effective treatment to improve reduced oocyte quality.

\section{LH Signaling: Experimental Animal IVM Studies}

In vitro maturation (IVM) oocyte culture systems have improved animal and human oocyte and embryo quality $[6$, 101]. The rationale of this approach is to synchronize oocyte nuclear and cytoplasmic maturation prior to completion of the first meiotic division. Premature resumption of meiosis is prevented to allow completion of normal nuclear and cytoplasmic maturation when oocytes are removed from follicles at oocyte retrieval. This allows oocyte cell cycle proteins to accumulate in the nucleus resulting in nuclear maturation. This also allows normal oocyte growth and duplication of cytoplasmic contents, i.e., ribosomes, Golgi, and mitochondria, and nuclear contents in preparation for the completion of the first and second meiotic cellular divisions of the oocyte.

This is accomplished, experimentally, by maintaining high cAMP levels in the cumulus-oocyte complex (COC) with phosphodiesterase inhibitors (PDE-I). Phosphodiesterases (PDE) breakdown cAMP which activates the oocyte CDK1/ cyclin $\mathrm{B}$ resulting in resumption of meiosis and completion of the first meiotic division. Thus, immature incompetent oocytes can grow and develop into competent oocytes by allowing synchronization of nuclear and cytoplasmic growth. IVM studies demonstrate that cAMP-modulated IVM oocyte maturation rates, fertilization rates, and embryo cleavage rates can be improved. The cattle industry routinely utilizes IVM to produce healthy embryos. A total of 400,000 healthy cattle embryos were produced in 2013. Four IVM systems have been developed: standard IVM, biphasic (moderate cAMP), moderate induced (moderate cAMP), and high induced (high cAMP) $[6,101,333]$.

Standard IVM protocols culture immature COCs in standard IVM media without cAMP modulators. IVM media are supplemented with FSH, LH, or HCG. Immature oocytes rapidly undergo spontaneous oocyte meiotic maturation. [165, 334]. Biphasic IVM systems utilize a phosphodiesterase inhibitor (PDE-I) for $24 \mathrm{~h}$. This maintains moderate follicle cAMP levels which prevents oocyte nuclear maturation. This 24 -h phase is followed by a PDE-I free 2nd phase which allows oocyte maturation to occur. The inhibition of oocyte nuclear maturation by cAMP was first demonstrated in the 1970s in mice and frogs [167, 335]. This approach improves mouse [336], bovine [337], and porcine [338] oocyte competence and embryo quality relative to standard IVM.

Induced IVM (high cAMP) protocols induce high cAMP levels, with cAMP stimulators, in the COC similar to the cAMP spike seen in vivo after the LH surge. Aktas et al. induced high cAMP levels in bovine oocytes with invasive adenylate cyclase. Ninety percent of the treated oocytes were maintained in meiotic arrest [339]. Funahashi et al. exposed porcine oocytes to the cAMP analogue dbc AMP [340]. Even though the oocyte maturation rate was not improved, oocyte quality was improved. Blastocyst rates were higher in the treated group compared with the untreated group (21.5\% vs. 9\%). Li et al. used forskolin (activates adenylyl cyclase) and IBMX (PDE-I) to increase follicle cAMP levels. This increased glutathione oocyte levels, reduced hydrogen peroxide levels, and reduced bovine oocyte oxidative stress. This improved oocyte and embryo quality [341].

Other novel IVM systems have also improved oocyte and embryo quality. EGF and AREG improve animal oocyte developmental competence [342]. Ritter et al. studied small (< $4 \mathrm{~mm}$ )- and medium-sized ( $>4 \mathrm{~mm}$ ) follicles, which represent low and moderate oocyte competence, respectively [343]. Denuded oocytes were matured in vitro in standard IVM media or IVM media supplemented with EGF. Cumulus cell EGFR gene expression and protein was measured with quantitative RT-PCR and western blot. Medium-sized follicles showed full cumulus cell expansion in response to EGF, while small follicles failed to expand. CC expansion gene (HAS2, PTGS2, TNFA1P6) mRNA expression was significantly lower in small follicles compared with medium follicles treated with EGF. EGFR mRNA expression levels were similar in small- and medium-sized follicles. EGFR protein and EGFR phosphorylation was increased in moderate- compared with small-sized follicles. EGF increased EGFR protein and EGFR phosphorylation in moderate-sized follicles, while EGFR protein and phosphorylation levels were undetectable in smallsized follicles. ERK1/2 phosphorylation was higher in moderate-sized follicles compared with small follicles. To determine whether native OSFs can cause CC expansion in small follicles, small follicles were co-cultured with denuded oocytes from medium-sized follicles and treated with EGF. Small follicles demonstrated full CC expansion. Native OSFs are probably acting via SMAD 2/3 since a SMAD antagonist prevented CC expansion. GDF9 and BMP15 did not 
induce CC expansion in small-sized follicles. Inseminated oocytes from moderate-sized follicles developed more blastocysts compared with oocytes from small follicles (45\% vs. $15 \%)$. Small follicles treated with OSFs and EGF developed more blastocysts compared with those treated with EGF only (34\% vs. $15 \%$ ). The authors concluded that EGF and OSFs interact to improve oocyte competence.

OSFs improve oocyte and embryo developmental competence. Hussein et al. treated bovine COCs with GDF9 or BMP15 during IVM maturation [344]. The blastocyst rate was improved compared with controls (55\% vs. $40 \%)$. GDF9 improved mouse fetal survival (40\% vs. 20\%) [345]. BMP15 improved oocyte and embryo quality by stimulating $\mathrm{CC}$ and oocyte gap junction activity [346].

CNP improves animal oocyte quality. Santiquet et al. preincubated murine COC with $\mathrm{CNP}, \mathrm{FSH}$, and BMP15 for 2 or $24 \mathrm{~h}$ [347]. Resumption of meiosis was prevented. Blastocyst rate $(71.9 \%$ vs. $53.3 \%)$ and implantation rate $(37.2 \%$ vs. $17.2 \%)$ were improved compared with controls after $96 \mathrm{~h}$ of culture.

These studies show that oocytes from larger follicles are more developmentally competent than oocytes from small follicles. The developmental competence of cultured oocytes can be improved with IVM protocols supplemented with cAMP modulators, EGF, AREG, OSFs, and CNP. The acquisition of oocyte competence is dependent on the accumulation of adequate cumulus cell EGFR, ERK1/2, and SMAD2/3 transcript levels and gap junction activity.

\section{LH Signaling: Experimental Human IVM Studies}

Experimental human IVM studies performed during the last 10 years demonstrate that human oocyte and embryo quality can be improved (Table 2). Nogueira et al. performed the first IVM prematuration culture (PMC) human oocyte study. They studied human GV oocytes retrieved from 12-mm follicles or less after standard controlled ovarian hyperstimulation $(\mathrm{COH})$ with FSH and triggered with HCG [93]. COCs were incubated with a PDE3-I for 24- or 48-h prematuration culture (PMC) period then washed and cultured in IVM media with FSH and EGF for $48 \mathrm{~h}$. This was followed by insemination with ICSI; the embryos were grown for 3 days. In the control IVM group, COCs were grown in IVM media with FSH and EGF for $48 \mathrm{~h}$. PDE3-I delayed meiotic progression, as 98\% of the PDE3-Itreated GV oocytes remained arrested. PDE3-I-treated GV oocytes achieved higher maturation rates compared with control oocytes ( 67 vs. $46 \% ; p=0.01$ ). The PMC treatment period did not improve fertilization or cleavage rates. In addition, higher oocyte maturation rates were found in COCs with moderate cell expansion compared with compacted COCs.
Shu et al. collected COCs from unstimulated and nonHCG-triggered 4-10-mm antral follicles by laparoscopy from 292 women mean age 34 [94]. A total of 730 COCs were cultured in IVM control media, or cilostamide (PDE3-I) alone, or forskolin (adenylate cyclase activator) alone, and combined cilostamide and forskolin in a 48-h PMC period followed by IVM for $24 \mathrm{~h}$. Metaphase II oocytes were inseminated with ICSI and embryos were grown for 5 days. PDE3-I delayed meiotic progression. Oocyte maturation and embryo cleavage rates were similar in all groups (Table 2). The fertilization rate was increased in the combined groups compared with controls (52 vs. $76 \%$ ). Gap junction communication (GJC) was prolonged 2-fold in the cilostamide + forskolin group compared with control. The authors concluded that the combined treatment, cilostamide and forskolin, increased follicle cAMP, delayed resumption of meiosis, and increased and maintaining GJC. This resulted in improved oocyte cytoplasmic maturation, and embryo quality as reflected in the increase in blastocyst rate. Further IVM studies are required to determine the optimal agents and dose and time intervals of PDE-I and AC activators.

Vanhoutte et al. stimulated patients with FSH 150 IU/day or Menopur (equal amounts of FSH- and HCG-driven LH activity) and triggered with HCG $5000 \mathrm{IU}$ when two follicles reached a diameter of $20 \mathrm{~mm}$ [95]. GV and MII oocytes were retrieved from $<10-\mathrm{mm}$-diameter follicles for the study. Retrieved MII oocytes were the in vivo controls. IVM media, Tissue Culture Medium 199, was supplemented with EGF. PMC media were composed of basal medium (Tissue Culture Medium 199) supplemented with $0.8 \%$ human serum albumin plus PDE3-I (cilostamide). Cumulus-enclosed oocytes (CEOs) were embedded in an extracellular matrix (ECM) solution composed of collagen with PMC media for $24 \mathrm{~h}$. The ECM solution allows the CEOs to maintain their three-dimensional (3D) tight structure. This preserves somatic cell-oocyte bidirectional communication which promotes oocyte quality. After the 24-h PMC period, COCs were cultured in IVM media for 24,30 , and $48 \mathrm{~h}$. CEO controls were grown in IVM media only, for $48 \mathrm{~h}$. MII oocytes were fertilized by ICSI. Fertilization was assessed at $16-18 \mathrm{~h}$ post-ICSI. Embryos were graded on days 2 and 3. PDE3-I delayed meiotic progression. Ninety percent of the oocytes grown in 3D PMC media were arrested at the GV stage. The MII rate $(60.6 \%$ vs. $81.6 \% ; p<0.05)$, fertilization rate $(27.3 \%$ vs. $59.6 \%)$, and embryo cleavage rate $(27.3 \%$ vs. $55.6 \%)$ were all higher in the 3D PMC group compared with the IVM conventional group (Table 2). Electron microscopy studies found that the 3D PMC method maintained the CEO 3D structure, cumulus-oocyte contacts were maintained, and transzonal projections were identified. Lucifer yellow dye coupling assay identified more functional gap junctions in the 3D PMC group compared with controls. They concluded that the 3D PMC period improved oocyte maturation and 
embryo cleavage rates reflecting an improvement in oocyte quality, and oocyte meiotic and cytoplasmic maturation. This improved oocyte quality may be related to preservation of cumulus-oocyte gap junctions.

Novel IVM culture systems supplemented with growth factors and other signaling molecules improve oocyte quality. Goud et al. studied the effect of EGF on oocyte quality. They obtained 289 spare germinal vesicle (GV) oocytes from 92 infertile patients stimulated with human menopausal gonadotropin (HMG), which were retrieved $36 \mathrm{~h}$ post-HCG 10,000 IU, and then inseminated with ICSI [97]. The mean age of the patients was 31.8 years. GV oocytes were cultured in IVM media supplemented with EGF for 12, 24, and $30 \mathrm{~h}$. GV oocytes were divided into two groups: group I, cumulusdenuded oocytes with and without EGF and group II, intact oocytes with and without EGF. At $30 \mathrm{~h}$, the MII rate in the denuded was higher in the oocytes supplemented with EGF $(64.3 \%$ vs. $33.9 \%)$ (Table 2). The fertilization rate in the denuded group was similar to that in the EGF- and non-EGFsupplemented oocytes. In the intact group, the fertilization rate was higher in the EGF-supplemented oocytes $(71.7 \%$ vs. $45.6 \%$ ). The day 3 cleavage rate was overall higher in the oocyte-intact EGF group. They concluded that retaining cumulus cells and adding EGF improve the MII, fertilization, and cleavage rates. This suggests improved oocyte meiotic and cytoplasmic maturation, and overall improved oocyte quality.

Ben-Ami et al. reported improved MII and embryo cleavage rates with IVM media supplemented with EGF and AREG [98]. Thirty patients were treated with standard $\mathrm{COH}$ stimulation, retrieval, and ICSI. A total of $105 \mathrm{GV}$ oocytes were cultured with IVM media supplemented with both AREG and EREG for $24 \mathrm{~h}$. The MII rate was increased in the supplemented group ( 75.5 vs. $36.5 \%, p<0.001)$. The fertilization and cleavage rates were not improved with supplementation; however, the higher MII rate allowed more embryos to be produced. This was the first study to show a positive effect of EGF and AREG on human oocyte maturation rate.

Sanchez et al. reported a new IVM strategy for immature oocytes retrieved from small follicles $(2-6 \mathrm{~mm})$ [99]. Thirty patients with PCOS, average age 28.9, were stimulated with Menopur for 3 days. HCG trigger was not given. All follicles were $<10 \mathrm{~mm}$ prior to retrieval. Control COCs were cultured in IVM media supplemented with HMG and HCG, and cultured for $30 \mathrm{~h}$. In the PMC/CNP group, COCs were collected in media supplemented with PDE3-I (IBMX), then washed and cultured in IVM media supplemented with FSH and CNP for $24 \mathrm{~h}$, and then washed and cultured in IVM media supplemented with AREG and FSH for $30 \mathrm{~h}$. MII oocytes were inseminated using ICSI. All experimental blastocysts were biopsied and analyzed for aneuploidy by nextgeneration sequencing (NGS). The oocyte maturation rate ( $48 \%$ vs. $70 \%$ ), the day 3 good-quality embryo rate $(23 \%$ vs. $43 \%$ ), and the blastocyst rate ( $8 \%$ vs. $18 \%$ ) were all increased in the PMC group compared with the control IVM group (Table 2). Transzonal projections (TZPs) were maintained in the PMC group which may explain improved oocyte competence in this group. The blastocyst aneuploidy rate (3 aneuploid/10) was not increased compared with standard ART. IVM/PMC with CNP improved oocyte maturation, fertilization, and blastocyst rates. This suggests that oocyte meiotic and cytoplasmic maturation and oocyte quality are improved. Whether IVM/PMC systems can reduce embryo aneuploidy rates is not known.

Madkour et al. reported a new rescue IVM approach [100]. All patients were stimulated with standard FSH doses, triggered with HCG, and oocyte retrieval was performed $36 \mathrm{~h}$ post-HCG. MII oocytes were inseminated with ICSI and cultured 5 or 6 days. They randomized $150 \mathrm{GV}$ oocytes from 47 patients with PCOS. Immature GV oocytes were randomized to four groups. The simple-IVM (S-IVM) protocol contained standard IVM media. In the autologous follicular fluid (AFFIVM) protocol, AFF was added to standard IVM media. AFF was collected from the study patients during the oocyte retrieval. In the heterologous follicular fluid (HFF-IVM) protocol, HFF was added to standard IVM media. HFF was taken from 7 women without PCOS with subsequent 100\% MII maturation. HFF was added to standard IVM media. In the heterologous follicular fluid/CGC (HFF/CGC-IVM) protocol, HFF and cumulus-granulosa cell (CGC) supernatant were added. CGC supernatant was obtained from 7 women without PCOS. FF was collected at egg retrieval, centrifuged, CGCs were collected and cultured for 3 days, and then supernatant was collected and added to IVM media. Immature oocytes were cultured for $24 \mathrm{~h}$. All IVM-matured MII oocytes were inseminated with ICSI and cultured to day 5 or 6 . The MII, cleavage, and blastocyst rates were higher in the HFF/CGCIVM group compared with standard IVM (Table 2). The CGC supernatant contains growth factors and cytokines which may be responsible for the improvement in maturation rate and embryo quality. The MII maturation rate in the HFF/CGC group of $79 \%$ and $65 \%$ day 5 blastocyst rate are similar to standard IVF MII and blastocyst rates.

Spits et al. treated 16 young (mean age was 28.7) PCOS women with Menopur $150 \mathrm{IU} /$ day starting on day 3 of the cycle for 3 days; ultrasound was performed on day 6 , and retrieval for immature oocytes was performed on day 7 on all patients $42 \mathrm{~h}$ after the last dose of Menopur [96]. HCG trigger was not given. COC oocytes were treated with PDE3-I (IBMX) for $1 \mathrm{~h}$ in standard IVM media. COCs were then washed and placed in IVM culture media supplemented with FSH for $40 \mathrm{~h}$, then the cumulus layer was removed, oocyte maturation was assessed, and ICSI was performed. The oocyte maturation rate was $50.2 \%(120 / 239)$, the fertilization rate was $68.3 \%(82 / 120)$, and the day 3 cleavage goodquality embryo rate was $30.5 \%$ (25/82). Chromosome 
analysis was performed on single blastomeres. Eighteen embryos were dissociated, individual blastomeres were washed, 136 cells were successfully amplified and analyzed with aCGH, and 123 cells gave results. Sixty-one percent (11/18) of the IVM embryos were mosaics. This is similar to the day 3 embryo mosaic rate in standard IVF.

These human IVM studies demonstrate that human oocyte quality can be improved. IVM/PMC culture systems supplemented with PDE-I, EGF, AREG, or CNP improve oocyte maturation, cleavage rate, and blastocyst rate compared with standard IVM systems (Table 2). IVM/PMC with PDE-I delays resumption of meiotic maturation by increasing cAMP in the COC. This allows the cytoplasmic and nuclear contents of the oocyte to grow and develop, thus allowing time for oocyte meiotic and cytoplasmic maturation. Improved oocyte meiotic maturation resulted in MII rates approaching $80 \%$. As a result of improved oocyte cytoplasmic maturation, the IVM fertilization rate approached $80 \%$, and cleavage rate approached 50-70\%. These IVM rates suggest that IVM may become a routine alternative ART for some patients in the near future. Oocyte and follicle gap junction activity and transzonal projections allowing bidirectional communication between oocyte-granulosa cells may be important mechanisms underlying oocyte quality. These studies also suggest that IVM/ PMC system embryo aneuploidy rates and mosaicism are not increased compared with standard IVF.

\section{Clinical Human IVM}

The first human oocyte IVM studies were performed over 50 years ago $[334,348]$. The first successful human IVM births were reported over 25 years ago [349, 350]. During the first 20 years of IVM, the pregnancy rates from IVM cycles were reduced by half compared with standard IVF [351-355]. The reduced IVM pregnancy rate was attributed to asynchrony between nuclear and cytoplasmic maturation [356].

Recent IVM studies demonstrate improved outcomes [357-360]. Walls et al. recently performed the first study that compared IVM and standard IVF blastocyst development [361]. They studied 56 PCOS patients ( 80 cycles) who were treated with IVM and 65 PCOS patients (98 cycles) treated with standard IVF. The IVM patients were treated with GonalF (recombinant FSH) 150 IU/day started on cycle day 2 after transvaginal ultrasound and was continued for 3-6 days. Transvaginal ultrasound was repeated on day 6 of the cycle, and oocyte retrieval was performed within $72 \mathrm{~h}$ after a $10-\mathrm{mm}$ follicle was observed. COCs were cultured for $24 \mathrm{~h}$ in G-2Plus media which is a bicarbonate-buffered media with hyaluronan and maternal serum. This was supplemented with FSH and hCG. MII oocytes were inseminated with ICSI. The total number of oocytes retrieved per patient was similar in the IVM and IVF groups (13.2 vs. 16.6\%). The maturation rate
( 73 vs. $80 \%$ ) and fertilization rate (68 vs. $77 \%$ ) were superior in the IVF group, and the good-quality blastocyst rate was the same in both groups (38 vs. $40 \%$ ). The live birth rate per transfer was superior in the IVF fresh transfer group compared with the IVM group (18.8 vs. $31.0 \%$ ), and similar in the frozen IVM and IVF groups (33.9 vs. $29.9 \%$ ). The cumulative live birth rate per egg retrieved was higher in the IVF group (41.3 vs. $55.1 \%)$. The miscarriage rate was higher in the fresh transfer IVM group compared with the fresh IVF group (36.8 vs. $19.0 \%$ ), and lower in the frozen transfer IVM group compared with the frozen IVF group (4.5 vs. $18.6 \%$ ). The birth weights and preterm labor rate were similar in both groups. The authors concluded that the efficiency gap between IVM and IVF is closing, and that IVM should be recommended for PCOS patients who have experienced OHSS with standard IVF.

Birth outcomes are similar in IVM and IVF children. Preterm birth rates and newborn birth weights are similar in IVM and IVF births [362, 363]. Congenital birth defects are not increased in IVM children [364, 365]. Childhood development is similar in IVM and IVF. Roesner et al. studied 21 children conceived by IVM [366]. At birth, weight, length, and head circumference were similar in IVM children compared with IVF controls. At age 2, weight, length, and head circumference and cognitive development were similar in IVM compared with IVF controls.

\section{Summary}

Here, we reviewed human LH signaling oocyte meiotic maturation studies. We found 89 human studies in the literature on this topic. These studies identified and characterized $24 \mathrm{LH}$ signaling proteins involved in oocyte meiotic maturation (Table 1). Coticchio et al. recently reviewed human oocyte maturation and similarly found $<50$ human studies in the literature on this topic [5]. These human studies suggest that the primary targets of the LH signal in the follicle are the CNP/ NPR2 system, the EGF/EGF receptor network, and gap junctions. The primary target of the LH signal in the oocyte is the MPF (CDK1/Cyclin B1). The activated MPF initiates resumption of meiosis by phosphorylating downstream proteins including SAC proteins, APC proteins, separase, securin, and cohesin. How these downstream proteins induce resumption of meiosis and completion of the first meiotic division including germinal vesical breakdown, chromosome condensation, and extrusion of the first polar body in humans is not known. Additionally, these LH signaling molecules may predict oocyte quality, a critical issue in assisted reproductive technology (ART); however, a reliable marker of oocyte quality still has not been identified.

These LH signaling pathway molecules also regulate oocyte competence. Human oocyte gene expression studies suggest that oocyte cell cycle proteins targeted by the LH signal 
are key regulators of oocyte developmental competence. Differences in cell cycle gene expression have been identified between human immature oocytes from primordial follicles and MII oocytes. Grondahl et al. found differences in securin, cyclin B1, separase, CDC20, aurora kinase (AURKC), BMP15, GDF9, EGF, and EGFR [82]. Riris et al. studied single human MII and GV oocyte cell cycle mRNA levels and found differences in CDK1, WEE2, AURKA, AURKC, MAP2k1, BUB1, BUB1B, CHEK1, MOS, and FYN [80]. Yanez et al. found differences in cell cycle gene expression profiles of viable and non-viable zygotes including CDK1, CDC25B, cyclins, BUB1, BUB1B, BUB3, MAD2L1, securin, ANAPCI, ANAPC4, ANAPC11, cohesion complex genes including SMC2, SMC3, and SMC4, BRCA1, TERF1, ERCC1, XRCC6, XAB2, RPA1, and MRE11A [81]. Reyes et al. studied cell cycle expression profiles in 10 oocytes ( $5 \mathrm{GV}, 5 \mathrm{MII}$ ) from young women and 10 oocytes (5 GV, 5 MII) from older women [79]. They found differences in CDK1. These studies suggest that the expression and abundance of these oocyte cell cycle transcripts may determine whether an oocyte acquires competence, and whether it is able to form a viable embryo.

Human oocyte quality can be improved with IVM/PMC manipulation of the LH signaling pathway (Table 2). Human oocyte IVM cultures supplemented with PDE-I [95], AREG [98], CNP [99], and heterologous follicular fluid/CGC [100] improve oocyte maturation and embryo quality. Experimental IVM oocyte maturation rates (range, 70-81.6\%) are approaching standard IVF maturation rates. Clinical IVM neonatal outcomes are similar to standard IVF outcomes. The IVM aneuploidy rate is not increased in day 3 embryos [96] and blastocysts [99]. These experimental IVM protocols may soon be introduced into clinical IVM practice further improving clinical IVM.

\section{Conclusion}

We found 89 papers in the literature that studied human LH signaling oocyte meiotic maturation. These studies identified 24 proteins involved in this process (Table 1). The proteins expressed in the human ovarian follicle compartment are signaling proteins, while the proteins expressed in human oocytes are primarily cell cycle proteins. The primary targets of the LH signal in the follicle are the CNP/NPR2 system, EGF network, and gap junctions (Fig. 2). The primary target of the LH signal in the oocyte is the CDK1/Cyclin B complex. These follicle/oocyte proteins are vitally important. They regulate human oocyte meiotic maturation, oocyte quality, and embryo quality. Remarkably, human oocyte and embryo quality is improved using IVM/PMC cumulus-oocyte culture systems that manipulate the LH signaling pathway (Table 2). The studies reviewed were mostly published during the last 10 years. Human oocyte maturation studies are very limited in number.
Human oocyte research is only beginning. Hopefully, human oocyte and embryo research will continue to increase in the future so that further insight into the cellular mechanisms that regulate oocyte and embryo quality can be acquired.

\section{Compliance with Ethical Standards}

Conflict of Interest The authors declare that they have no conflict of interest.

Abbreviations $A P C / C$, anaphase-promoting complex or cyclosome; $A R E G$, amphiregulin; $B M P$, bone morphogenetic protein; $B u b$, budding uninhibited by benzimidizole protein; $C C$, cumulus cells; $C D C$, cell division cycle; $C D K 1$, cyclin-dependent kinase $1 ; C N P$, C type natriuretic peptide; $C G C$, cumulus-granulosa cell; $C O C$, cumulus-oocyte complex; $E G F$, epidermal growth factor; $E G F-L P$, epidermal growth factor-like peptides; $E R K$, extracellular signal-regulated kinases; $F S H$, follicle-stimulating hormone; $G C$, granulosa cells; $G D F 9$, growth differentiation factor 9; GJ, gap junctions; GPR3, G protein-coupled receptor 3; GVBD, germinal vesicle breakdown; Has2, hyaluronan synthase $2 ; H M G$, human menopausal gonadotropin; IVM, in vitro maturation; $L H$, luteinizing hormone; $M A D$, mitotic arrest-deficient protein; $M A P K$, mitogen-activated protein kinases; $M I$, metaphase I; $M I I$, metaphase II; NPPC, natriuretic peptide precursor $\mathrm{C} ; N P R 2$, natriuretic peptide receptor 2; $O Q$, oocyte quality; $O S F$, oocyte-secreted factor; $P D E$, phosphodiesterase; $P P$, protein phosphatase; Ptgs2, prostaglandin-endoperoxide synthase 2; $S A C$, spindle assembly checkpoint; $T G F$, transforming growth factors; $T K R$, tyrosine kinase receptor; Tnfaip, tumor necrosis factor alpha-induced protein $6 ; T M$, transmembrane; TZP, transzonal projections

Open Access This article is licensed under a Creative Commons Attribution 4.0 International License, which permits use, sharing, adaptation, distribution and reproduction in any medium or format, as long as you give appropriate credit to the original author(s) and the source, provide a link to the Creative Commons licence, and indicate if changes were made. The images or other third party material in this article are included in the article's Creative Commons licence, unless indicated otherwise in a credit line to the material. If material is not included in the article's Creative Commons licence and your intended use is not permitted by statutory regulation or exceeds the permitted use, you will need to obtain permission directly from the copyright holder. To view a copy of this licence, visit http://creativecommons.org/licenses/by/4.0/.

\section{References}

1. Edson MA, Nagaraja AK, Matzuk MM. The mammalian ovary from genesis to revelation. Endocr Rev. 2009;30:624-712.

2. Greenwald GaR SK. Follicular development and its control. In: Knobil E, editor. The physiology of reproduction, vol. 1. 2nd ed. New York: Raven Press; 1994. p. 629-724.

3. Pincus G. The eggs of mammals. Experimental Biology Monographs. New York, NY; The Macmillian Company; 1936.

4. Sanchez F, Smitz J. Molecular control of oogenesis. Biochim Biophys Acta. 1822;2012:1896-912.

5. Coticchio G, Dal Canto M, Mignini Renzini M, Guglielmo MC, Brambillasca F, Turchi D, et al. Oocyte maturation: gametesomatic cells interactions, meiotic resumption, cytoskeletal dynamics and cytoplasmic reorganization. Hum Reprod Update. 2015;21:427-54. 
6. Gilchrist RB. Recent insights into oocyte-follicle cell interactions provide opportunities for the development of new approaches to in vitro maturation. Reprod Fertil Dev. 2011;23:23-31.

7. Li R, Albertini DF. The road to maturation: somatic cell interaction and self-organization of the mammalian oocyte. Nat Rev Mol Cell Biol. 2013;14:141-52.

8. Mehlmann LM. Stops and starts in mammalian oocytes: recent advances in understanding the regulation of meiotic arrest and oocyte maturation. Reproduction. 2005;130:791-9.

9. Conti M, Hsieh M, Zamah AM, Oh JS. Novel signaling mechanisms in the ovary during oocyte maturation and ovulation. Mol Cell Endocrinol. 2012;356:65-73.

10. Jaffe LA, Egbert JR. Regulation of mammalian oocyte meiosis by intercellular communication within the ovarian follicle. Annu Rev Physiol. 2017;79:237-60.

11. Adhikari D, Liu K. The regulation of maturation promoting factor during prophase I arrest and meiotic entry in mammalian oocytes. Mol Cell Endocrinol. 2014;382:480-7.

12. Downs SM. Regulation of the G2/M transition in rodent oocytes. Mol Reprod Dev. 2010;77:566-85.

13. Liu L, Kong N, Xia G, Zhang M. Molecular control of oocyte meiotic arrest and resumption. Reprod Fertil Dev. 2013;25: 463-71.

14. Sun QY, Miao YL, Schatten H. Towards a new understanding on the regulation of mammalian oocyte meiosis resumption. Cell Cycle. 2009;8:2741-7.

15. Zhang M, Ouyang H, Xia G. The signal pathway of gonadotrophins-induced mammalian oocyte meiotic resumption. Mol Hum Reprod. 2009;15:399-409.

16. Kawamura K, Cheng Y, Kawamura N, Takae S, Okada A, Kawagoe Y, et al. Pre-ovulatory LH/hCG surge decreases Ctype natriuretic peptide secretion by ovarian granulosa cells to promote meiotic resumption of pre-ovulatory oocytes. Hum Reprod. 2011;26:3094-101.

17. Robinson JW, Zhang M, Shuhaibar LC, Norris RP, Geerts A, Wunder F, et al. Luteinizing hormone reduces the activity of the NPR2 guanylyl cyclase in mouse ovarian follicles, contributing to the cyclic GMP decrease that promotes resumption of meiosis in oocytes. Dev Biol. 2012;366:308-16.

18. Solc P, Schultz RM, Motlik J. Prophase I arrest and progression to metaphase I in mouse oocytes: comparison of resumption of meiosis and recovery from G2-arrest in somatic cells. Mol Hum Reprod. 2010;16:654-64.

19. Patrizio P, Silber S. Improving IVF: is there a limit to our ability to manipulate human biology? J Assist Reprod Genet. 2017;34:7-9.

20. Silber SJ, Kato K, Aoyama N, Yabuuchi A, Skaletsky H, Fan Y, et al. Intrinsic fertility of human oocytes. Fertil Steril. 2017;107: 1232-7.

21. Eppig JJ, O'Brien M, Wigglesworth K. Mammalian oocyte growth and development in vitro. Mol Reprod Dev. 1996;44: 260-73.

22. Messinger SM, Albertini DF. Centrosome and microtubule dynamics during meiotic progression in the mouse oocyte. J Cell Sci. 1991;100(Pt 2):289-98.

23. Dumesic DA, Meldrum DR, Katz-Jaffe MG, Krisher RL, Schoolcraft WB. Oocyte environment: follicular fluid and cumulus cells are critical for oocyte health. Fertil Steril. 2015;103:303-16.

24. van den Hurk R, Zhao J. Formation of mammalian oocytes and their growth, differentiation and maturation within ovarian follicles. Theriogenology. 2005;63:1717-51.

25. Assou S, Anahory T, Pantesco V, Le Carrour T, Pellestor F, Klein $\mathrm{B}$, et al. The human cumulus-oocyte complex gene-expression profile. Hum Reprod. 2006;21:1705-19.

26. Jeppesen JV, Kristensen SG, Nielsen ME, Humaidan P, Dal Canto $\mathrm{M}$, Fadini R, et al. LH-receptor gene expression in human granulosa and cumulus cells from antral and preovulatory follicles. J Clin Endocrinol Metab. 2012;97:E1524-31.

27. Yung Y, Aviel-Ronen S, Maman E, Rubinstein N, Avivi C, Orvieto $\mathrm{R}$, et al. Localization of luteinizing hormone receptor protein in the human ovary. Mol Hum Reprod. 2014;20:844-9.

28. Regan SL, Knight PG, Yovich JL, Stanger JD, Leung Y, Arfuso F, et al. Dysregulation of granulosal bone morphogenetic protein receptor $1 \mathrm{~B}$ density is associated with reduced ovarian reserve and the age-related decline in human fertility. Mol Cell Endocrinol. 2016;425:84-93.

29. Regan SL, Knight PG, Yovich JL, Stanger JD, Leung Y, Arfuso F, et al. Infertility and ovarian follicle reserve depletion are associated with dysregulation of the FSH and LH receptor density in human antral follicles. Mol Cell Endocrinol. 2017;446:40-51.

30. Sasson R, Rimon E, Dantes A, Cohen T, Shinder V, LandBracha A, et al. Gonadotrophin-induced gene regulation in human granulosa cells obtained from IVF patients. Modulation of steroidogenic genes, cytoskeletal genes and genes coding for apoptotic signalling and protein kinases. Mol Hum Reprod. 2004;10:299-311.

31. Yang SH, Son WY, Yoon SH, Ko Y, Lim JH. Correlation between in vitro maturation and expression of $\mathrm{LH}$ receptor in cumulus cells of the oocytes collected from PCOS patients in HCG-primed IVM cycles. Hum Reprod. 2005;20:2097-103.

32. Maman E, Yung Y, Kedem A, Yerushalmi GM, Konopnicki S, Cohen B, et al. High expression of luteinizing hormone receptors messenger RNA by human cumulus granulosa cells is in correlation with decreased fertilization. Fertil Steril. 2012;97:592-8.

33. Huang Y, Zhao Y, Yu Y, Li R, Lin S, Zhang C, et al. Altered amphiregulin expression induced by diverse luteinizing hormone receptor reactivity in granulosa cells affects IVF outcomes. Reprod BioMed Online. 2015;30:593-601.

34. Liu W, Xin Q, Wang X, Wang S, Wang H, Zhang W, et al. Estrogen receptors in granulosa cells govern meiotic resumption of pre-ovulatory oocytes in mammals. Cell Death Dis. 2017;8: e2662.

35. Zamah AM, Hsieh M, Chen J, Vigne JL, Rosen MP, Cedars MI, et al. Human oocyte maturation is dependent on LH-stimulated accumulation of the epidermal growth factor-like growth factor, amphiregulin. Hum Reprod. 2010;25:2569-78.

36. Hsieh M, Zamah AM, Conti M. Epidermal growth factor-like growth factors in the follicular fluid: role in oocyte development and maturation. Semin Reprod Med. 2009;27:52-61.

37. Tamura M, Sasano H, Suzuki T, Fukaya T, Funayama Y, Takayama K, et al. Expression of epidermal growth factors and epidermal growth factor receptor in normal cycling human ovaries. Hum Reprod. 1995;10:1891-6.

38. Maruo T, Ladines-Llave CA, Samoto T, Matsuo H, Manalo AS, Ito $\mathrm{H}$, et al. Expression of epidermal growth factor and its receptor in the human ovary during follicular growth and regression. Endocrinology. 1993;132:924-31.

39. Westergaard LG, Andersen CY. Epidermal growth factor (EGF) in human preovulatory follicles. Hum Reprod. 1989;4:257-60.

40. Reeka N, Berg FD, Brucker C. Presence of transforming growth factor alpha and epidermal growth factor in human ovarian tissue and follicular fluid. Hum Reprod. 1998;13:2199-205.

41. Ben-Ami I, Freimann S, Armon L, Dantes A, Strassburger D, Friedler S, et al. PGE2 up-regulates EGF-like growth factor biosynthesis in human granulosa cells: new insights into the coordination between PGE2 and LH in ovulation. Mol Hum Reprod. 2006;12:593-9.

42. Freimann S, Ben-Ami I, Dantes A, Ron-El R, Amsterdam A. EGF-like factor epiregulin and amphiregulin expression is regulated by gonadotropins/cAMP in human ovarian follicular cells. Biochem Biophys Res Commun. 2004;324:829-34. 
43. Rimon E, Sasson R, Dantes A, Land-Bracha A, Amsterdam A. Gonadotropin-induced gene regulation in human granulosa cells obtained from IVF patients: modulation of genes coding for growth factors and their receptors and genes involved in cancer and other diseases. Int J Oncol. 2004;24:1325-38.

44. Feuerstein P, Cadoret V, Dalbies-Tran R, Guerif F, Bidault R, Royere D. Gene expression in human cumulus cells: one approach to oocyte competence. Hum Reprod. 2007;22:3069-77.

45. Hofmann GE, Scott RT Jr, Brzyski RG, Jones HW Jr. Immunoreactive epidermal growth factor concentrations in follicular fluid obtained from in vitro fertilization. Fertil Steril. 1990;54: 303-7.

46. Inoue Y, Miyamoto S, Fukami T, Shirota K, Yotsumoto F, Kawarabayashi T. Amphiregulin is much more abundantly expressed than transforming growth factor-alpha and epidermal growth factor in human follicular fluid obtained from patients undergoing in vitro fertilization-embryo transfer. Fertil Steril. 2009;91:1035-41.

47. Winterhager E, Kidder GM. Gap junction connexins in female reproductive organs: implications for women's reproductive health. Hum Reprod Update. 2015;21:340-52.

48. Cepni I, Kahraman N, Ocal P, Idil M, Uludag S. Expression and comparison of gap junction protein connexin 37 in granulosa cells aspirates from follicles of poor responder and nonpoor responder patients. Fertil Steril. 2008;89:417-20.

49. Wang HX, Tong D, El-Gehani F, Tekpetey FR, Kidder GM. Connexin expression and gap junctional coupling in human cumulus cells: contribution to embryo quality. J Cell Mol Med. 2009;13:972-84.

50. Furger C, Cronier L, Poirot C, Pouchelet M. Human granulosa cells in culture exhibit functional cyclic AMP-regulated gap junctions. Mol Hum Reprod. 1996;2:541-8.

51. Chang HM, Cheng JC, Taylor E, Leung PC. Oocyte-derived BMP15 but not GDF9 down-regulates connexin43 expression and decreases gap junction intercellular communication activity in immortalized human granulosa cells. Mol Hum Reprod. 2014;20:373-83.

52. Buffat C, Boubred F, Mondon F, Chelbi ST, Feuerstein JM, Lelievre-Pegorier M, et al. Kidney gene expression analysis in a rat model of intrauterine growth restriction reveals massive alterations of coagulation genes. Endocrinology. 2007;148:5549-57.

53. Zhang Y, Xu Y, Xue Q, Kuai Y, Wang S, Shang J. Comparison of connexin43 in cumulus cells between poor and non-poor responders undergoing in vitro fertilization. J Reprod Med. 2017:62:50-4.

54. Hasegawa J, Yanaihara A, Iwasaki S, Mitsukawa K, Negishi M, Okai T. Reduction of connexin 43 in human cumulus cells yields good embryo competence during ICSI. J Assist Reprod Genet. 2007;24:463-6.

55. Haas J, Ophir L, Barzilay E, Machtinger R, Yung Y, Orvieto R, et al. Standard human chorionic gonadotropin versus double trigger for final oocyte maturation results in different granulosa cells gene expressions: a pilot study. Fertil Steril. 2016;106:653-9 e651.

56. Kristensen SG, Andersen K, Clement CA, Franks S, Hardy K, Andersen CY. Expression of TGF-beta superfamily growth factors, their receptors, the associated SMADs and antagonists in five isolated size-matched populations of pre-antral follicles from normal human ovaries. Mol Hum Reprod. 2014;20:293-308.

57. Ribeiro A, Freitas C, Matos L, Gouveia A, Gomes F, Silva Carvalho JL, et al. Age-related expression of TGF beta family receptors in human cumulus oophorus cells. J Assist Reprod Genet. 2017;34:1121-9.

58. Kaivo-oja N, Jeffery LA, Ritvos O, Mottershead DG. Smad signalling in the ovary. Reprod Biol Endocrinol. 2006;4:21.
59. Bertoldo MJ, Cheung MY, Sia ZK, Agapiou D, Corley SM, Wilkins MR, et al. Non-canonical cyclic AMP SMAD1/5/8 signalling in human granulosa cells. Mol Cell Endocrinol. 2019.

60. Hobeika E, Armouti M, Kala H, Fierro MA, Winston NJ, Scoccia $\mathrm{B}$, et al. Oocyte-secreted factors synergize with FSH to promote aromatase expression in primary human cumulus cells. J Clin Endocrinol Metab. 2019;104:1667-76.

61. Aaltonen J, Laitinen MP, Vuojolainen K, Jaatinen R, HorelliKuitunen N, Seppa L, et al. Human growth differentiation factor 9 (GDF-9) and its novel homolog GDF-9B are expressed in oocytes during early folliculogenesis. J Clin Endocrinol Metab. 1999;84:2744-50.

62. Shi FT, Cheung AP, Huang HF, Leung PC. Effects of endogenous growth differentiation factor 9 on activin A-induced inhibin $\mathrm{B}$ production in human granulosa-lutein cells. J Clin Endocrinol Metab. 2009;94:5108-16.

63. Hreinsson JG, Scott JE, Rasmussen C, Swahn ML, Hsueh AJ, Hovatta O. Growth differentiation factor-9 promotes the growth, development, and survival of human ovarian follicles in organ culture. J Clin Endocrinol Metab. 2002;87:316-21.

64. Ota T, Choi KB, Gilks CB, Leung PC, Auersperg N. Cell typeand stage-specific changes in HOXA7 protein expression in human ovarian folliculogenesis: possible role of GDF-9. Differentiation. 2006;74:1-10.

65. Shi FT, Cheung AP, Huang HF, Leung PC. Growth differentiation factor 9 (GDF9) suppresses follistatin and follistatin-like 3 production in human granulosa-lutein cells. PLoS One. 2011;6: e22866.

66. Chang HM, Fang L, Cheng JC, Klausen C, Sun YP, Leung PC. Growth differentiation factor 8 down-regulates pentraxin 3 in human granulosa cells. Mol Cell Endocrinol. 2015;404:82-90.

67. Li H, Chang HM, Shi Z, Leung PCK. SNAIL mediates TGFbeta1-induced downregulation of pentraxin 3 expression in human granulosa cells. Endocrinology. 2018;159:1644-57.

68. Huang Q, Cheung AP, Zhang Y, Huang HF, Auersperg N, Leung PC. Effects of growth differentiation factor 9 on cell cycle regulators and ERK42/44 in human granulosa cell proliferation. Am J Phys Endocrinol Metab. 2009;296:E1344-53.

69. de Resende LO, Vireque AA, Santana LF, Moreno DA, De Sa Rosa e Silva AC, Ferriani RA, et al. Single-cell expression analysis of BMP15 and GDF9 in mature oocytes and BMPR2 in cumulus cells of women with polycystic ovary syndrome undergoing controlled ovarian hyperstimulation. J Assist Reprod Genet. 2012;29:1057-65.

70. Teixeira Filho FL, Baracat EC, Lee TH, Suh CS, Matsui M, Chang RJ, et al. Aberrant expression of growth differentiation factor-9 in oocytes of women with polycystic ovary syndrome. J Clin Endocrinol Metab. 2002;87:1337-44.

71. Wei LN, Huang R, Li LL, Fang C, Li Y, Liang XY. Reduced and delayed expression of GDF9 and BMP15 in ovarian tissues from women with polycystic ovary syndrome. J Assist Reprod Genet. 2014:31:1483-90.

72. Li Y, Li RQ, Ou SB, Zhang NF, Ren L, Wei LN, et al. Increased GDF9 and BMP15 mRNA levels in cumulus granulosa cells correlate with oocyte maturation, fertilization, and embryo quality in humans. Reprod Biol Endocrinol. 2014;12:81.

73. Margulis S, Abir R, Felz C, Nitke S, Krissi H, Fisch B. Bone morphogenetic protein 15 expression in human ovaries from fetuses, girls, and women. Fertil Steril. 2009;92:1666-73.

74. Khalaf M, Morera J, Bourret A, Reznik Y, Denoual C, Herlicoviez M, et al. BMP system expression in GCs from polycystic ovary syndrome women and the in vitro effects of BMP4, BMP6, and BMP7 on GC steroidogenesis. Eur J Endocrinol. 2013;168:437-44. 
75. Chang HM, Cheng JC, Klausen C, Leung PC. BMP15 suppresses progesterone production by down-regulating StAR via ALK3 in human granulosa cells. Mol Endocrinol. 2013;27:2093-104.

76. Shi FT, Cheung AP, Klausen C, Huang HF, Leung PC. Growth differentiation factor 9 reverses activin A suppression of steroidogenic acute regulatory protein expression and progesterone production in human granulosa-lutein cells. J Clin Endocrinol Metab. 2010;95:E172-80.

77. Wu YT, Wang TT, Chen XJ, Zhu XM, Dong MY, Sheng JZ, et al. Bone morphogenetic protein-15 in follicle fluid combined with age may differentiate between successful and unsuccessful poor ovarian responders. Reprod Biol Endocrinol. 2012;10:116.

78. DiLuigi A, Weitzman VN, Pace MC, Siano LJ, Maier D, Mehlmann LM. Meiotic arrest in human oocytes is maintained by a Gs signaling pathway. Biol Reprod. 2008;78:667-72.

79. Reyes JM, Silva E, Chitwood JL, Schoolcraft WB, Krisher RL, Ross PJ. Differing molecular response of young and advanced maternal age human oocytes to IVM. Hum Reprod. 2017;32:2199-208.

80. Riris S, Webster P, Homer H. Digital multiplexed mRNA analysis of functionally important genes in single human oocytes and correlation of changes in transcript levels with oocyte protein expression. Fertil Steril. 2014;101:857-64.

81. Yanez LZ, Han J, Behr BB, Reijo Pera RA, Camarillo DB. Human oocyte developmental potential is predicted by mechanical properties within hours after fertilization. Nat Commun. 2016;7:10809.

82. Grondahl ML, Borup R, Vikesa J, Ernst E, Andersen CY, LykkeHartmann K. The dormant and the fully competent oocyte: comparing the transcriptome of human oocytes from primordial follicles and in metaphase II. Mol Hum Reprod. 2013;19:600-17.

83. Sang Q, Li B, Kuang Y, Wang X, Zhang Z, Chen B, et al. Homozygous mutations in WEE2 cause fertilization failure and female infertility. Am J Hum Genet. 2018;102:649-57.

84. Cunat S, Anahory T, Berthenet C, Hedon B, Franckhauser C, Fernandez A, et al. The cell cycle control protein cdc $25 \mathrm{C}$ is present, and phosphorylated on serine 214 in the transition from germinal vesicle to metaphase II in human oocyte meiosis. Mol Reprod Dev. 2008;75:1176-84.

85. Gasca S, Pellestor F, Assou S, Loup V, Anahory T, Dechaud H, et al. Identifying new human oocyte marker genes: a microarray approach. Reprod BioMed Online. 2007;14:175-83.

86. Steuerwald N, Cohen J, Herrera RJ, Sandalinas M, Brenner CA. Association between spindle assembly checkpoint expression and maternal age in human oocytes. Mol Hum Reprod. 2001;7:49-55.

87. Steuerwald NM, Bermudez MG, Wells D, Munne S, Cohen J. Maternal age-related differential global expression profiles observed in human oocytes. Reprod BioMed Online. 2007;14:700-8.

88. Grondahl ML, Yding Andersen C, Bogstad J, Nielsen FC, Meinertz H, Borup R. Gene expression profiles of single human mature oocytes in relation to age. Hum Reprod. 2010;25:957-68.

89. Prieto I, Tease C, Pezzi N, Buesa JM, Ortega S, Kremer L, et al. Cohesin component dynamics during meiotic prophase I in mammalian oocytes. Chromosom Res. 2004;12:197-213.

90. Garcia-Cruz R, Brieno MA, Roig I, Grossmann M, Velilla E, Pujol A, et al. Dynamics of cohesin proteins REC8, STAG3, SMC1 beta and SMC3 are consistent with a role in sister chromatid cohesion during meiosis in human oocytes. Hum Reprod. 2010;25:2316-27.

91. Duncan FE, Hornick JE, Lampson MA, Schultz RM, Shea LD, Woodruff TK. Chromosome cohesion decreases in human eggs with advanced maternal age. Aging Cell. 2012;11:1121-4.

92. Tsutsumi M, Fujiwara R, Nishizawa H, Ito M, Kogo H, Inagaki H, et al. Age-related decrease of meiotic cohesins in human oocytes. PLoS One. 2014;9:e96710.
93. Nogueira D, Ron-El R, Friedler S, Schachter M, Raziel A, Cortvrindt $\mathrm{R}$, et al. Meiotic arrest in vitro by phosphodiesterase 3 -inhibitor enhances maturation capacity of human oocytes and allows subsequent embryonic development. Biol Reprod. 2006;74:177-84.

94. Shu YM, Zeng HT, Ren Z, Zhuang GL, Liang XY, Shen HW, et al. Effects of cilostamide and forskolin on the meiotic resumption and embryonic development of immature human oocytes. Hum Reprod. 2008;23:504-13.

95. Vanhoutte L, Nogueira D, Dumortier F, De Sutter P. Assessment of a new in vitro maturation system for mouse and human cumulus-enclosed oocytes: three-dimensional prematuration culture in the presence of a phosphodiesterase 3-inhibitor. Hum Reprod. 2009;24:1946-59.

96. Spits C, Guzman L, Mertzanidou A, Jacobs K, Ortega-Hrepich C, Gilchrist RB, et al. Chromosome constitution of human embryos generated after in vitro maturation including 3-isobutyl-1methylxanthine in the oocyte collection medium. Hum Reprod. 2015;30:653-63.

97. Goud PT, Goud AP, Qian C, Laverge H, Van der Elst J, De Sutter $\mathrm{P}$, et al. In-vitro maturation of human germinal vesicle stage oocytes: role of cumulus cells and epidermal growth factor in the culture medium. Hum Reprod. 1998;13:1638-44.

98. Ben-Ami I, Komsky A, Bern O, Kasterstein E, Komarovsky D, Ron-El R. In vitro maturation of human germinal vesicle-stage oocytes: role of epidermal growth factor-like growth factors in the culture medium. Hum Reprod. 2011;26:76-81.

99. Sanchez F, Lolicato F, Romero S, De Vos M, Van Ranst H, Verheyen $\mathrm{G}$, et al. An improved IVM method for cumulusoocyte complexes from small follicles in polycystic ovary syndrome patients enhances oocyte competence and embryo yield. Hum Reprod. 2017;32:2056-68.

100. Madkour A, Bouamoud N, Kaarouch I, Louanjli N, Saadani B, Assou S, et al. Follicular fluid and supernatant from cultured cumulus-granulosa cells improve in vitro maturation in patients with polycystic ovarian syndrome. Fertil Steril. 2018;110:710-9.

101. Gilchrist RB, Luciano AM, Richani D, Zeng HT, Wang X, Vos $\mathrm{MD}$, et al. Oocyte maturation and quality: role of cyclic nucleotides. Reproduction. 2016;152:R143-57.

102. Pedersen T, Peters H. Proposal for a classification of oocytes and follicles in the mouse ovary. J Reprod Fertil. 1968;17:555-7.

103. Hsueh AJ, Kawamura K, Cheng Y, Fauser BC. Intraovarian control of early folliculogenesis. Endocr Rev. 2015;36:1-24.

104. McGee EA, Hsueh AJ. Initial and cyclic recruitment of ovarian follicles. Endocr Rev. 2000;21:200-14.

105. Gougeon A. Dynamics of follicular growth in the human: a model from preliminary results. Hum Reprod. 1986;1:81-7.

106. Gougeon A. Regulation of ovarian follicular development in primates: facts and hypotheses. Endocr Rev. 1996;17:121-55.

107. Yen SSC, Strauss JF, Barbieri RL. Yen \& Jaffe's reproductive endocrinology : physiology, pathophysiology, and clinical management. 7th ed. Philadelphia: Elsevier/Saunders.

108. Hodgen GD. The dominant ovarian follicle. Fertil Steril. 1982;38: 281-300.

109. diZerega GS, Marut EL, Turner CK, Hodgen GD. Asymmetrical ovarian function during recruitment and selection of the dominant follicle in the menstrual cycle of the rhesus monkey. J Clin Endocrinol Metab. 1980;51:698-701.

110. Brailly S, Gougeon A, Milgrom E, Bomsel-Helmreich O, Papiernik E. Androgens and progestins in the human ovarian follicle: differences in the evolution of preovulatory, healthy nonovulatory, and atretic follicles. J Clin Endocrinol Metab. 1981;53:128-34.

111. Bomsel-Helmreich O, Huyen LV, Durand-Gasselin I, SalatBaroux J, Antoine JM. Timing of nuclear maturation and cumulus dissociation in human oocytes stimulated with clomiphene citrate, 
human menopausal gonadotropin, and human chorionic gonadotropin. Fertil Steril. 1987;48:586-95.

112. Esch FS, Mason AJ, Cooksey K, Mercado M, Shimasaki S. Cloning and DNA sequence analysis of the cDNA for the precursor of the beta chain of bovine follicle stimulating hormone. Proc Natl Acad Sci U S A. 1986;83:6618-21.

113. Direito A, Bailly S, Mariani A, Ecochard R. Relationships between the luteinizing hormone surge and other characteristics of the menstrual cycle in normally ovulating women. Fertil Steril. 2013;99:279-85.

114. Sawyer CH, Everett JW, Markee JE. A neural factor in the mechanism by which estrogen induces the release of luteinizing hormone in the rat. Endocrinology. 1949;44:218-33.

115. Amoss M, Burgus R, Blackwell R, Vale W, Fellows R, Guillemin R. Purification, amino acid composition and Nterminus of the hypothalamic luteinizing hormone releasing factor (LRF) of ovine origin. Biochem Biophys Res Commun. 1971;44:205-10.

116. Schally AV, Arimura A, Baba Y, Nair RM, Matsuo H, Redding $\mathrm{TW}$, et al. Isolation and properties of the FSH and LH-releasing hormone. Biochem Biophys Res Commun. 1971;43:393-9.

117. Sarkar DK, Chiappa SA, Fink G, Sherwood NM. Gonadotropinreleasing hormone surge in pro-oestrous rats. Nature. 1976;264: $461-3$.

118. Xia L, Van Vugt D, Alston EJ, Luckhaus J, Ferin M. A surge of gonadotropin-releasing hormone accompanies the estradiolinduced gonadotropin surge in the rhesus monkey. Endocrinology. 1992;131:2812-20.

119. Moenter SM, Caraty A, Karsch FJ. The estradiol-induced surge of gonadotropin-releasing hormone in the ewe. Endocrinology. 1990;127:1375-84.

120. Herbison AE. Physiology of the gonadotropin-releasing hormone neuronal network. In: PT NJD, Pfaff DW, JRG C, de Kretser DM, Richards JS, Wassarman PM, editors. Knobil and Neill's physiology of reproduction. Vol 1: Elsevier Academic Press; 2006. p. 1415-82.

121. Knobil E. The neuroendocrine control of the menstrual cycle. Recent Prog Horm Res. 1980;36:53-88.

122. Knobil E. The GnRH pulse generator. Am J Obstet Gynecol. 1990;163:1721-7.

123. Moenter SM, DeFazio AR, Pitts GR, Nunemaker CS. Mechanisms underlying episodic gonadotropin-releasing hormone secretion. Front Neuroendocrinol. 2003;24:79-93.

124. Barry J. Immunohistochemistry of luteinizing hormone-releasing hormone-producing neurons of the vertebrates. Int Rev Cytol. 1979;60:179-221.

125. Levine JE, Ramirez VD. Luteinizing hormone-releasing hormone release during the rat estrous cycle and after ovariectomy, as estimated with push-pull cannulae. Endocrinology. 1982;111:1439-48.

126. Chappell PE, White RS, Mellon PL. Circadian gene expression regulates pulsatile gonadotropin-releasing hormone $(\mathrm{GnRH})$ secretory patterns in the hypothalamic GnRH-secreting GT1-7 cell line. J Neurosci. 2003;23:11202-13.

127. Moenter SM. Identified GnRH neuron electrophysiology: a decade of study. Brain Res. 2010;1364:10-24.

128. Herbison AE. Multimodal influence of estrogen upon gonadotropin-releasing hormone neurons. Endocr Rev. 1998;19: 302-30.

129. Moenter SM, Chu Z, Christian CA. Neurobiological mechanisms underlying oestradiol negative and positive feedback regulation of gonadotrophin-releasing hormone neurones. J Neuroendocrinol. 2009;21:327-33.

130. Arroyo A, Kim B, Rasmusson RL, Bett G, Yeh J. Hyperpolarization-activated cation channels are expressed in rat hypothalamic gonadotropin-releasing hormone $(\mathrm{GnRH})$ neurons and immortalized GnRH neurons. J Soc Gynecol Investig. 2006;13:442-50.

131. Arroyo A, Kim BS, Biehl A, Yeh J, Bett GC. Expression of kv4.3 voltage-gated potassium channels in rat gonadotrophin-releasing hormone $(\mathrm{GnRH})$ neurons during the estrous cycle. Reprod Sci. 2011;18:136-44.

132. Clarke IJ, Cummins JT. The temporal relationship between gonadotropin releasing hormone $(\mathrm{GnRH})$ and luteinizing hormone $(\mathrm{LH})$ secretion in ovariectomized ewes. Endocrinology. 1982;111: 1737-9.

133. Urbanski HF, Pickle RL, Ramirez VD. Simultaneous measurement of gonadotropin-releasing hormone, luteinizing hormone, and follicle-stimulating hormone in the orchidectomized rat. Endocrinology. 1988;123:413-9.

134. Dierschke DJ, Bhattacharya AN, Atkinson LE, Knobil E. Circhoral oscillations of plasma LH levels in the ovariectomized rhesus monkey. Endocrinology. 1970;87:850-3.

135. Midgley AR Jr, Jaffe RB. Regulation of human gonadotropins. X. Episodic fluctuation of LH during the menstrual cycle. J Clin Endocrinol Metab. 1971;33:962-9.

136. Yen SS, Tsai CC, Naftolin F, Vandenberg G, Ajabor L. Pulsatile patterns of gonadotropin release in subjects with and without ovarian function. J Clin Endocrinol Metab. 1972;34:671-5.

137. Santen RJ, Bardin CW. Episodic luteinizing hormone secretion in man. Pulse analysis, clinical interpretation, physiologic mechanisms. J Clin Invest. 1973;52:2617-28.

138. Ascoli M, Fanelli F, Segaloff DL. The lutropin/ choriogonadotropin receptor, a 2002 perspective. Endocr Rev. 2002;23:141-74.

139. Kusuda S, Dufau ML. Purification and characterization of the rat ovarian receptor for luteinizing hormone. Structural studies of subunit interaction. J Biol Chem. 1986;261:16161-8.

140. McFarland KC, Sprengel R, Phillips HS, Kohler M, Rosemblit N, Nikolics K, et al. Lutropin-choriogonadotropin receptor: an unusual member of the $\mathrm{G}$ protein-coupled receptor family. Science. 1989;245:494-9.

141. Rajaniemi HJ, Keinanen KP, Kellokumpu S, Petaja-Repo UE, Metsikko MK. Molecular structure of the luteinizing hormone receptor. Biol Reprod. 1989;40:1-12.

142. Atger M, Misrahi M, Sar S, Le Flem L, Dessen P, Milgrom E. Structure of the human luteinizing hormone-choriogonadotropin receptor gene: unusual promoter and $5^{\prime}$ non-coding regions. Mol Cell Endocrinol. 1995;111:113-23.

143. Hunzicker-Dunn M. Selective activation of rabbit ovarian protein kinase isozymes in rabbit ovarian follicles and corpora lutea. J Biol Chem. 1981;256:12185-93.

144. Puett D, Li Y, Angelova K, Demars G, Meehan TP, Fanelli F, et al. Structure-function relationships of the luteinizing hormone receptor. Ann N Y Acad Sci. 2005;1061:41-54.

145. Puett D, Li Y, DeMars G, Angelova K, Fanelli F. A functional transmembrane complex: the luteinizing hormone receptor with bound ligand and G protein. Mol Cell Endocrinol. 2007;260262:126-36.

146. Amsterdam A, Berkowitz A, Nimrod A, Kohen F. Aggregation of luteinizing hormone receptors in granulosa cells: a possible mechanism of desensitization to the hormone. Proc Natl Acad Sci U S A. $1980 ; 77: 3440-4$.

147. Amsterdam A, Koch Y, Lieberman ME, Lindner HR. Distribution of binding sites for human chorionic gonadotropin in the preovulatory follicle of the rat. J Cell Biol. 1975;67:894-900.

148. Kammerman S, Ross J. Increase in numbers of gonadotropin receptors on granulosa cells during follicle maturation. J Clin Endocrinol Metab. 1975;41:546-50.

149. Peng XR, Hsueh AJ, LaPolt PS, Bjersing L, Ny T. Localization of luteinizing hormone receptor messenger ribonucleic acid 
expression in ovarian cell types during follicle development and ovulation. Endocrinology. 1991;129:3200-7.

150. Hoffman YM, Peegel H, Sprock MJ, Zhang QY, Menon KM. Evidence that human chorionic gonadotropin/luteinizing hormone receptor down-regulation involves decreased levels of receptor messenger ribonucleic acid. Endocrinology. 1991;128:388-93.

151. LaPolt PS, Oikawa M, Jia XC, Dargan C, Hsueh AJ. Gonadotropin-induced up- and down-regulation of rat ovarian LH receptor message levels during follicular growth, ovulation and luteinization. Endocrinology. 1990;126:3277-9.

152. Lu DL, Peegel H, Mosier SM, Menon KM. Loss of lutropin/ human choriogonadotropin receptor messenger ribonucleic acid during ligand-induced down-regulation occurs post transcriptionally. Endocrinology. 1993;132:235-40.

153. Meduri G, Vu Hai MT, Jolivet A, Takemori S, Kominami S, Driancourt MA, et al. Comparison of cellular distribution of LH receptors and steroidogenic enzymes in the porcine ovary. $\mathrm{J}$ Endocrinol. 1996;148:435-46.

154. Peegel H, Randolph J Jr, Midgley AR, Menon KM. In situ hybridization of luteinizing hormone/human chorionic gonadotropin receptor messenger ribonucleic acid during hormone-induced downregulation and the subsequent recovery in rat corpus luteum. Endocrinology. 1994;135:1044-51.

155. Segaloff DL, Wang HY, Richards JS. Hormonal regulation of luteinizing hormone/chorionic gonadotropin receptor mRNA in rat ovarian cells during follicular development and luteinization. Mol Endocrinol. 1990;4:1856-65.

156. Rao MC, Richards JS, Midgley AR Jr, Reichert LE Jr. Regulation of gonadotropin receptors by luteinizing hormone in granulosa cells. Endocrinology. 1977;101:512-23.

157. Conti M, Andersen CB, Richard F, Mehats C, Chun SY, Horner K, et al. Role of cyclic nucleotide signaling in oocyte maturation. Mol Cell Endocrinol. 2002;187:153-9.

158. Lei ZM, Mishra S, Zou W, Xu B, Foltz M, Li X, et al. Targeted disruption of luteinizing hormone/human chorionic gonadotropin receptor gene. Mol Endocrinol. 2001;15:184-200.

159. Zhang FP, Poutanen M, Wilbertz J, Huhtaniemi I. Normal prenatal but arrested postnatal sexual development of luteinizing hormone receptor knockout (LuRKO) mice. Mol Endocrinol. 2001;15:172-83.

160. Themmen APN, Huhtaniemi IT. Mutations of gonadotropins and gonadotropin receptors: elucidating the physiology and pathophysiology of pituitary-gonadal function. Endocr Rev. 2000;21: 551-83.

161. Toledo SP, Brunner HG, Kraaij R, Post M, Dahia PL, Hayashida $\mathrm{CY}$, et al. An inactivating mutation of the luteinizing hormone receptor causes amenorrhea in a $46, \mathrm{XX}$ female. J Clin Endocrinol Metab. 1996;81:3850-4.

162. Latronico AC, Chai Y, Arnhold IJ, Liu X, Mendonca BB, Segaloff DL. A homozygous microdeletion in helix 7 of the luteinizing hormone receptor associated with familial testicular and ovarian resistance is due to both decreased cell surface expression and impaired effector activation by the cell surface receptor. Mol Endocrinol. 1998;12:442-50.

163. Jakimiuk AJ, Weitsman SR, Navab A, Magoffin DA. Luteinizing hormone receptor, steroidogenesis acute regulatory protein, and steroidogenic enzyme messenger ribonucleic acids are overexpressed in thecal and granulosa cells from polycystic ovaries. J Clin Endocrinol Metab. 2001;86:1318-23.

164. Pincus G, Enzmann EV. The comparative behavior of mammalian eggs in vivo and in vitro : I. The activation of ovarian eggs. J Exp Med. 1935;62:665-75.

165. Edwards RG. Maturation in vitro of mouse, sheep, cow, pig, rhesus monkey and human ovarian oocytes. Nature. 1965;208: $349-51$.
166. Anderson E, Albertini DF. Gap junctions between the oocyte and companion follicle cells in the mammalian ovary. J Cell Biol. 1976;71:680-6.

167. Cho WK, Stern S, Biggers JD. Inhibitory effect of dibutyryl cAMP on mouse oocyte maturation in vitro. J Exp Zool. 1974;187:383-6.

168. Schultz RM, Montgomery RR, Belanoff JR. Regulation of mouse oocyte meiotic maturation: implication of a decrease in oocyte cAMP and protein dephosphorylation in commitment to resume meiosis. Dev Biol. 1983;97:264-73.

169. Mehlmann LM, Jones TL, Jaffe LA. Meiotic arrest in the mouse follicle maintained by a Gs protein in the oocyte. Science. 2002;297:1343-5.

170. Horner K, Livera G, Hinckley M, Trinh K, Storm D, Conti M. Rodent oocytes express an active adenylyl cyclase required for meiotic arrest. Dev Biol. 2003;258:385-96.

171. Mehlmann LM, Saeki Y, Tanaka S, Brennan TJ, Evsikov AV, Pendola FL, et al. The Gs-linked receptor GPR3 maintains meiotic arrest in mammalian oocytes. Science. 2004;306:1947-50.

172. Norris RP, Ratzan WJ, Freudzon M, Mehlmann LM, Krall J, Movsesian MA, et al. Cyclic GMP from the surrounding somatic cells regulates cyclic AMP and meiosis in the mouse oocyte. Development. 2009;136:1869-78.

173. Jankowski M, Reis AM, Mukaddam-Daher S, Dam TV, Farookhi R, Gutkowska J. C-type natriuretic peptide and the guanylyl cyclase receptors in the rat ovary are modulated by the estrous cycle. Biol Reprod. 1997;56:59-66.

174. Zhang M, Su YQ, Sugiura K, Xia G, Eppig JJ. Granulosa cell ligand NPPC and its receptor NPR2 maintain meiotic arrest in mouse oocytes. Science. 2010;330:366-9.

175. Geister KA, Brinkmeier ML, Hsieh M, Faust SM, Karolyi IJ, Perosky JE, et al. A novel loss-of-function mutation in Npr2 clarifies primary role in female reproduction and reveals a potential therapy for acromesomelic dysplasia, Maroteaux type. Hum Mol Genet. 2013;22:345-57.

176. Tsuji T, Kiyosu C, Akiyama K, Kunieda T. CNP/NPR2 signaling maintains oocyte meiotic arrest in early antral follicles and is suppressed by EGFR-mediated signaling in preovulatory follicles. Mol Reprod Dev. 2012;79:795-802.

177. Wang W, Song MH, Miura K, Fujiwara M, Nawa N, Ohata Y, et al. Acromesomelic dysplasia, type maroteaux caused by novel loss-of-function mutations of the NPR2 gene: three case reports. Am J Med Genet A. 2016;170A:426-34.

178. Shuhaibar LC, Egbert JR, Norris RP, Lampe PD, Nikolaev $\mathrm{VO}$, Thunemann $\mathrm{M}$, et al. Intercellular signaling via cyclic GMP diffusion through gap junctions restarts meiosis in mouse ovarian follicles. Proc Natl Acad Sci U S A. 2015;112:5527-32.

179. Liu X, Xie F, Zamah AM, Cao B, Conti M. Multiple pathways mediate luteinizing hormone regulation of cGMP signaling in the mouse ovarian follicle. Biol Reprod. 2014;91:9.

180. Norris RP, Freudzon M, Nikolaev VO, Jaffe LA. Epidermal growth factor receptor kinase activity is required for gap junction closure and for part of the decrease in ovarian follicle cGMP in response to LH. Reproduction. 2010;140:655-62.

181. Conti M, Hsieh M, Park JY, Su YQ. Role of the epidermal growth factor network in ovarian follicles. Mol Endocrinol. 2006;20:715-23.

182. Dekel N, Sherizly I. Epidermal growth factor induces maturation of rat follicle-enclosed oocytes. Endocrinology. 1985;116:406-9.

183. Downs SM. Specificity of epidermal growth factor action on maturation of the murine oocyte and cumulus oophorus in vitro. Biol Reprod. 1989;41:371-9.

184. Park JY, Su YQ, Ariga M, Law E, Jin SL, Conti M. EGF-like growth factors as mediators of $\mathrm{LH}$ action in the ovulatory follicle. Science. 2004;303:682-4. 
185. Shimada M, Hernandez-Gonzalez I, Gonzalez-Robayna I, Richards JS. Paracrine and autocrine regulation of epidermal growth factor-like factors in cumulus oocyte complexes and granulosa cells: key roles for prostaglandin synthase 2 and progesterone receptor. Mol Endocrinol. 2006;20:1352-65.

186. Yamashita Y, Shimada M. The release of EGF domain from EGFlike factors by a specific cleavage enzyme activates the EGFRMAPK3/1 pathway in both granulosa cells and cumulus cells during the ovulation process. J Reprod Dev. 2012;58:510-4.

187. Hsieh M, Lee D, Panigone S, Horner K, Chen R, Theologis A, et al. Luteinizing hormone-dependent activation of the epidermal growth factor network is essential for ovulation. Mol Cell Biol. 2007;27:1914-24.

188. Reizel Y, Elbaz J, Dekel N. Sustained activity of the EGF receptor is an absolute requisite for $\mathrm{LH}$-induced oocyte maturation and cumulus expansion. Mol Endocrinol. 2010;24:402-11.

189. Herbst RS. Review of epidermal growth factor receptor biology. Int J Radiat Oncol Biol Phys. 2004;59:21-6.

190. Feng P, Catt KJ, Knecht M. Transforming growth factor beta regulates the inhibitory actions of epidermal growth factor during granulosa cell differentiation. J Biol Chem. 1986;261:14167-70.

191. Fan HY, Liu Z, Shimada M, Sterneck E, Johnson PF, Hedrick SM, et al. MAPK3/1 (ERK1/2) in ovarian granulosa cells are essential for female fertility. Science. 2009;324:938-41.

192. Panigone S, Hsieh M, Fu M, Persani L, Conti M. Luteinizing hormone signaling in preovulatory follicles involves early activation of the epidermal growth factor receptor pathway. Mol Endocrinol. 2008;22:924-36.

193. Hsieh M, Thao K, Conti M. Genetic dissection of epidermal growth factor receptor signaling during luteinizing hormoneinduced oocyte maturation. PLoS One. 2011;6:e21574.

194. Vaccari S, Weeks JL 2nd, Hsieh M, Menniti FS, Conti M. Cyclic GMP signaling is involved in the luteinizing hormonedependent meiotic maturation of mouse oocytes. Biol Reprod. 2009;81:595-604.

195. Nicholson SM, Bruzzone R. Gap junctions: getting the message through. Curr Biol. 1997;7:R340-4.

196. Simon AM, Goodenough DA. Diverse functions of vertebrate gap junctions. Trends Cell Biol. 1998;8:477-83.

197. Gilula NB, Epstein ML, Beers WH. Cell-to-cell communication and ovulation. A study of the cumulus-oocyte complex. J Cell Biol. 1978;78:58-75.

198. Gershon E, Plaks V, Dekel N. Gap junctions in the ovary: expression, localization and function. Mol Cell Endocrinol. 2008;282:18-25.

199. Kidder GM, Mhawi AA. Gap junctions and ovarian folliculogenesis. Reproduction. 2002;123:613-20.

200. Granot I, Bechor E, Barash A, Dekel N. Connexin43 in rat oocytes: developmental modulation of its phosphorylation. Biol Reprod. 2002;66:568-73.

201. Teilmann SC. Differential expression and localisation of connexin-37 and connexin-43 in follicles of different stages in the 4-week-old mouse ovary. Mol Cell Endocrinol. 2005;234: 27-35.

202. Richard S, Baltz JM. Prophase I arrest of mouse oocytes mediated by natriuretic peptide precursor $\mathrm{C}$ requires GJA1 (connexin-43) and GJA4 (connexin-37) gap junctions in the antral follicle and cumulus-oocyte complex. Biol Reprod. 2014;90:137.

203. Sherizly I, Galiani D, Dekel N. Regulation of oocyte maturation: communication in the rat cumulus-oocyte complex. Hum Reprod. 1988;3:761-6.

204. Wert SE, Larsen WJ. Meiotic resumption and gap junction modulation in the cultured rat cumulus-oocyte complex. Gamete Res. 1989;22:143-62.

205. Downs SM, Daniel SA, Eppig JJ. Induction of maturation in cumulus cell-enclosed mouse oocytes by follicle-stimulating hormone and epidermal growth factor: evidence for a positive stimulus of somatic cell origin. J Exp Zool. 1988;245:86-96.

206. Sela-Abramovich S, Edry I, Galiani D, Nevo N, Dekel N. Disruption of gap junctional communication within the ovarian follicle induces oocyte maturation. Endocrinology. 2006;147:2280-6.

207. Norris RP, Freudzon M, Mehlmann LM, Cowan AE, Simon AM, Paul DL, et al. Luteinizing hormone causes MAP kinasedependent phosphorylation and closure of connexin 43 gap junctions in mouse ovarian follicles: one of two paths to meiotic resumption. Development. 2008;135:3229-38.

208. Granot I, Dekel N. Phosphorylation and expression of connexin43 ovarian gap junction protein are regulated by luteinizing hormone. J Biol Chem. 1994;269:30502-9.

209. Sasseville M, Gagnon MC, Guillemette C, Sullivan R, Gilchrist $\mathrm{RB}$, Richard FJ. Regulation of gap junctions in porcine cumulusoocyte complexes: contributions of granulosa cell contact, gonadotropins, and lipid rafts. Mol Endocrinol. 2009;23:700-10.

210. Carabatsos MJ, Sellitto C, Goodenough DA, Albertini DF. Oocyte-granulosa cell heterologous gap junctions are required for the coordination of nuclear and cytoplasmic meiotic competence. Dev Biol. 2000;226:167-79.

211. Simon AM, Goodenough DA, Li E, Paul DL. Female infertility in mice lacking connexin 37. Nature. 1997;385:525-9.

212. Kumar TR, Wang Y, Lu N, Matzuk MM. Follicle stimulating hormone is required for ovarian follicle maturation but not male fertility. Nat Genet. 1997;15:201-4.

213. Sirard MA, Desrosier S, Assidi M. In vivo and in vitro effects of FSH on oocyte maturation and developmental competence. Theriogenology. 2007;68(Suppl 1):S71-6.

214. Eppig JJ. Oocyte control of ovarian follicular development and function in mammals. Reproduction. 2001;122:829-38.

215. Eppig JJ, Chesnel F, Hirao Y, O’Brien MJ, Pendola FL, Watanabe $\mathrm{S}$, et al. Oocyte control of granulosa cell development: how and why. Hum Reprod. 1997;12:127-32.

216. Eppig JJ, Wigglesworth K, Pendola FL. The mammalian oocyte orchestrates the rate of ovarian follicular development. Proc Natl Acad Sci U S A. 2002;99:2890-4.

217. Erickson GF, Shimasaki S. The role of the oocyte in folliculogenesis. Trends Endocrinol Metab. 2000;11:193-8.

218. Matzuk MM, Burns KH, Viveiros MM, Eppig JJ. Intercellular communication in the mammalian ovary: oocytes carry the conversation. Science. 2002;296:2178-80.

219. McNatty KP, Moore LG, Hudson NL, Quirke LD, Lawrence SB, Reader K, et al. The oocyte and its role in regulating ovulation rate: a new paradigm in reproductive biology. Reproduction. 2004;128:379-86.

220. Gilchrist RB, Ritter LJ, Armstrong DT. Oocyte-somatic cell interactions during follicle development in mammals. Anim Reprod Sci. 2004;82-83:431-46.

221. Li Q, McKenzie LJ, Matzuk MM. Revisiting oocyte-somatic cell interactions: in search of novel intrafollicular predictors and regulators of oocyte developmental competence. Mol Hum Reprod. 2008; 14:673-8.

222. Juengel JL, McNatty KP. The role of proteins of the transforming growth factor-beta superfamily in the intraovarian regulation of follicular development. Hum Reprod Update. 2005;11:143-60.

223. Moore RK, Erickson GF, Shimasaki S. Are BMP-15 and GDF-9 primary determinants of ovulation quota in mammals? Trends Endocrinol Metab. 2004;15:356-61.

224. Erickson GF, Shimasaki S. The spatiotemporal expression pattern of the bone morphogenetic protein family in rat ovary cell types during the estrous cycle. Reprod Biol Endocrinol. 2003;1:9.

225. Cakmak H, Franciosi F, Zamah AM, Cedars MI, Conti M. Dynamic secretion during meiotic reentry integrates the function 
of the oocyte and cumulus cells. Proc Natl Acad Sci U S A. 2016;113:2424-9.

226. el-Fouly MA, Cook B, Nekola M, Nalbandov AV. Role of the ovum in follicular luteinization. Endocrinology. 1970;87:286-93.

227. Dong J, Albertini DF, Nishimori K, Kumar TR, Lu N, Matzuk MM. Growth differentiation factor-9 is required during early ovarian folliculogenesis. Nature. 1996;383:531-5.

228. Buccione R, Vanderhyden BC, Caron PJ, Eppig JJ. FSH-induced expansion of the mouse cumulus oophorus in vitro is dependent upon a specific factor(s) secreted by the oocyte. Dev Biol. 1990;138:16-25.

229. Vanderhyden BC, Caron PJ, Buccione R, Eppig JJ. Developmental pattern of the secretion of cumulus expansionenabling factor by mouse oocytes and the role of oocytes in promoting granulosa cell differentiation. Dev Biol. 1990;140: 307-17.

230. Gilchrist RB, Lane M, Thompson JG. Oocyte-secreted factors: regulators of cumulus cell function and oocyte quality. Hum Reprod Update. 2008;14:159-77.

231. Knight PG, Glister C. TGF-beta superfamily members and ovarian follicle development. Reproduction. 2006;132:191-206.

232. McPherron AC, Lee SJ. GDF-3 and GDF-9: two new members of the transforming growth factor-beta superfamily containing a novel pattern of cysteines. J Biol Chem. 1993;268:3444-9.

233. Chang H, Brown CW, Matzuk MM. Genetic analysis of the mammalian transforming growth factor-beta superfamily. Endocr Rev. 2002;23:787-823.

234. Vitt UA, Mazerbourg S, Klein C, Hsueh AJ. Bone morphogenetic protein receptor type II is a receptor for growth differentiation factor-9. Biol Reprod. 2002;67:473-80.

235. Paradis F, Novak S, Murdoch GK, Dyck MK, Dixon WT, Foxcroft GR. Temporal regulation of BMP2, BMP6, BMP15, GDF9, BMPR1A, BMPR1B, BMPR2 and TGFBR1 mRNA expression in the oocyte, granulosa and theca cells of developing preovulatory follicles in the pig. Reproduction. 2009;138:115-29.

236. Shimasaki S, Moore RK, Otsuka F, Erickson GF. The bone morphogenetic protein system in mammalian reproduction. Endocr Rev. 2004;25:72-101.

237. Moore RK, Otsuka F, Shimasaki S. Molecular basis of bone morphogenetic protein-15 signaling in granulosa cells. J Biol Chem. 2003;278:304-10.

238. Elvin JA, Yan C, Matzuk MM. Oocyte-expressed TGF-beta superfamily members in female fertility. Mol Cell Endocrinol. 2000;159:1-5.

239. Hayashi M, McGee EA, Min G, Klein C, Rose UM, van Duin M, et al. Recombinant growth differentiation factor-9 (GDF-9) enhances growth and differentiation of cultured early ovarian follicles. Endocrinology. 1999;140:1236-44.

240. Vitt UA, Hayashi M, Klein C, Hsueh AJ. Growth differentiation factor-9 stimulates proliferation but suppresses the folliclestimulating hormone-induced differentiation of cultured granulosa cells from small antral and preovulatory rat follicles. Biol Reprod. 2000;62:370-7.

241. Nilsson EE, Skinner MK. Growth and differentiation factor-9 stimulates progression of early primary but not primordial rat ovarian follicle development. Biol Reprod. 2002;67:1018-24.

242. Otsuka F, McTavish KJ, Shimasaki S. Integral role of GDF-9 and BMP-15 in ovarian function. Mol Reprod Dev. 2011;78:9-21.

243. Orisaka M, Orisaka S, Jiang JY, Craig J, Wang Y, Kotsuji F, et al. Growth differentiation factor 9 is antiapoptotic during follicular development from preantral to early antral stage. Mol Endocrinol. 2006;20:2456-68.

244. Carabatsos MJ, Elvin J, Matzuk MM, Albertini DF. Characterization of oocyte and follicle development in growth differentiation factor-9-deficient mice. Dev Biol. 1998;204:373-84.
245. de Castro FC, Cruz MH, Leal CL. Role of growth differentiation factor 9 and bone morphogenetic protein 15 in ovarian function and their importance in mammalian female fertility - a review. Asian Australas J Anim Sci. 2016;29:1065-74.

246. Elvin JA, Clark AT, Wang P, Wolfman NM, Matzuk MM. Paracrine actions of growth differentiation factor-9 in the mammalian ovary. Mol Endocrinol. 1999;13:1035-48.

247. Gui LM, Joyce IM. RNA interference evidence that growth differentiation factor-9 mediates oocyte regulation of cumulus expansion in mice. Biol Reprod. 2005;72:195-9.

248. Su YQ, Sugiura K, Wigglesworth K, O’Brien MJ, Affourtit JP, Pangas SA, et al. Oocyte regulation of metabolic cooperativity between mouse cumulus cells and oocytes: BMP15 and GDF9 control cholesterol biosynthesis in cumulus cells. Development. 2008;135:111-21.

249. Sugiura K, Su YQ, Diaz FJ, Pangas SA, Sharma S, Wigglesworth $\mathrm{K}$, et al. Oocyte-derived BMP15 and FGFs cooperate to promote glycolysis in cumulus cells. Development. 2007;134:2593-603.

250. Li Q, Pangas SA, Jorgez CJ, Graff JM, Weinstein M, Matzuk MM. Redundant roles of SMAD2 and SMAD3 in ovarian granulosa cells in vivo. Mol Cell Biol. 2008;28:7001-11.

251. Pangas SA, Li X, Robertson EJ, Matzuk MM. Premature luteinization and cumulus cell defects in ovarian-specific Smad4 knockout mice. Mol Endocrinol. 2006;20:1406-22.

252. Peng J, Li Q, Wigglesworth K, Rangarajan A, Kattamuri C, Peterson RT, et al. Growth differentiation factor 9:bone morphogenetic protein 15 heterodimers are potent regulators of ovarian functions. Proc Natl Acad Sci U S A. 2013;110:E776-85.

253. Dixit H, Rao LK, Padmalatha V, Kanakavalli M, Deenadayal M, Gupta N, et al. Mutational screening of the coding region of growth differentiation factor 9 gene in Indian women with ovarian failure. Menopause. 2005;12:749-54.

254. Kovanci E, Rohozinski J, Simpson JL, Heard MJ, Bishop CE, Carson SA. Growth differentiating factor-9 mutations may be associated with premature ovarian failure. Fertil Steril. 2007;87: $143-6$.

255. Laissue P, Christin-Maitre S, Touraine P, Kuttenn F, Ritvos O, Aittomaki $\mathrm{K}$, et al. Mutations and sequence variants in GDF9 and BMP15 in patients with premature ovarian failure. Eur J Endocrinol. 2006;154:739-44.

256. Wang TT, Ke ZH, Song Y, Chen LT, Chen XJ, Feng C, et al. Identification of a mutation in GDF9 as a novel cause of diminished ovarian reserve in young women. Hum Reprod. 2013;28: 2473-81.

257. Pangas SA, Jorgez CJ, Matzuk MM. Growth differentiation factor 9 regulates expression of the bone morphogenetic protein antagonist gremlin. J Biol Chem. 2004;279:32281-6.

258. Varani S, Elvin JA, Yan C, DeMayo J, DeMayo FJ, Horton HF, et al. Knockout of pentraxin 3, a downstream target of growth differentiation factor- 9 , causes female subfertility. Mol Endocrinol. 2002;16:1154-67.

259. Cillo F, Brevini TA, Antonini S, Paffoni A, Ragni G, Gandolfi F. Association between human oocyte developmental competence and expression levels of some cumulus genes. Reproduction. 2007; $134: 645-50$

260. McKenzie LJ, Pangas SA, Carson SA, Kovanci E, Cisneros P, Buster JE, et al. Human cumulus granulosa cell gene expression: a predictor of fertilization and embryo selection in women undergoing IVF. Hum Reprod. 2004;19:2869-74.

261. Gode F, Gulekli B, Dogan E, Korhan P, Dogan S, Bige O, et al. Influence of follicular fluid GDF9 and BMP15 on embryo quality. Fertil Steril. 2011;95:2274-8.

262. Sanfins A, Rodrigues P, Albertini DF. GDF-9 and BMP-15 direct the follicle symphony. J Assist Reprod Genet. 2018;35:1741-50.

263. Yoshino O, McMahon HE, Sharma S, Shimasaki S. A unique preovulatory expression pattern plays a key role in the 
physiological functions of BMP-15 in the mouse. Proc Natl Acad Sci U S A. 2006;103:10678-83.

264. Diaz FJ, Wigglesworth K, Eppig JJ. Oocytes determine cumulus cell lineage in mouse ovarian follicles. J Cell Sci. 2007; 120:1330-40.

265. Dragovic RA, Ritter LJ, Schulz SJ, Amato F, Thompson JG, Armstrong DT, et al. Oocyte-secreted factor activation of SMAD $2 / 3$ signaling enables initiation of mouse cumulus cell expansion. Biol Reprod. 2007;76:848-57.

266. Su YQ, Sugiura K, Li Q, Wigglesworth K, Matzuk MM, Eppig JJ. Mouse oocytes enable LH-induced maturation of the cumulusoocyte complex via promoting EGF receptor-dependent signaling. Mol Endocrinol. 2010;24:1230-9.

267. Hussein TS, Froiland DA, Amato F, Thompson JG, Gilchrist RB. Oocytes prevent cumulus cell apoptosis by maintaining a morphogenic paracrine gradient of bone morphogenetic proteins. J Cell Sci. 2005;118:5257-68.

268. Wigglesworth K, Lee KB, O’Brien MJ, Peng J, Matzuk MM, Eppig JJ. Bidirectional communication between oocytes and ovarian follicular somatic cells is required for meiotic arrest of mammalian oocytes. Proc Natl Acad Sci U S A. 2013;110:E3723-9.

269. Otsuka F, Yao Z, Lee T, Yamamoto S, Erickson GF, Shimasaki S. Bone morphogenetic protein-15. Identification of target cells and biological functions. J Biol Chem. 2000;275:39523-8.

270. Galloway SM, McNatty KP, Cambridge LM, Laitinen MP, Juengel JL, Jokiranta TS, et al. Mutations in an oocytederived growth factor gene (BMP15) cause increased ovulation rate and infertility in a dosage-sensitive manner. Nat Genet. 2000;25:279-83.

271. Braw-Tal R, McNatty KP, Smith P, Heath DA, Hudson NL, Phillips DJ, et al. Ovaries of ewes homozygous for the X-linked Inverdale gene (FecXI) are devoid of secondary and tertiary follicles but contain many abnormal structures. Biol Reprod. 1993;49: 895-907.

272. McNatty KP, Juengel JL, Wilson T, Galloway SM, Davis GH. Genetic mutations influencing ovulation rate in sheep. Reprod Fertil Dev. 2001;13:549-55.

273. Chang HM, Qiao J, Leung PC. Oocyte-somatic cell interactions in the human ovary-novel role of bone morphogenetic proteins and growth differentiation factors. Hum Reprod Update. 2016;23:1-18.

274. Chang HM, Cheng JC, Leung PC. Theca-derived BMP4 and BMP7 down-regulate connexin43 expression and decrease gap junction intercellular communication activity in immortalized human granulosa cells. J Clin Endocrinol Metab. 2013;98:E437-45.

275. Di Pasquale E, Beck-Peccoz P, Persani L. Hypergonadotropic ovarian failure associated with an inherited mutation of human bone morphogenetic protein-15 (BMP15) gene. Am J Hum Genet. 2004;75:106-11.

276. Persani L, Rossetti R, Di Pasquale E, Cacciatore C, Fabre S. The fundamental role of bone morphogenetic protein 15 in ovarian function and its involvement in female fertility disorders. Hum Reprod Update. 2014;20:869-83.

277. Sugiyama R, Fuzitou A, Takahashi C, Akutagawa O, Ito H, Nakagawa K, et al. Bone morphogenetic protein 2 may be a good predictor of success in oocyte fertilization during assisted reproductive technology. Hum Cell. 2010;23:83-8.

278. Demiray SB, Yilmaz O, Goker ENT, Tavmergen E, Calimlioglu N, Sezerman U, et al. Expression of the bone morphogenetic protein-2 (BMP2) in the human cumulus cells as a biomarker of oocytes and embryo quality. J Hum Reprod Sci. 2017;10:194-200.

279. Hanevik HI, Hilmarsen HT, Skjelbred CF, Tanbo T, Kahn JA. A single nucleotide polymorphism in BMP15 is associated with high response to ovarian stimulation. Reprod BioMed Online. 2011;23: $97-104$
280. Masui Y. From oocyte maturation to the in vitro cell cycle: the history of discoveries of maturation-promoting factor (MPF) and cytostatic factor (CSF). Differentiation. 2001;69:1-17.

281. Lohka MJ, Hayes MK, Maller JL. Purification of maturationpromoting factor, an intracellular regulator of early mitotic events. Proc Natl Acad Sci U S A. 1988;85:3009-13.

282. Wasserman WJ, Masui Y. A cytoplasmic factor promoting oocyte maturation: its extraction and preliminary characterization. Science. 1976;191:1266-8.

283. Labbe JC, Capony JP, Caput D, Cavadore JC, Derancourt J, Kaghad M, et al. MPF from starfish oocytes at first meiotic metaphase is a heterodimer containing one molecule of cdc2 and one molecule of cyclin B. EMBO J. 1989;8:3053-8.

284. Lee MG, Nurse P. Complementation used to clone a human homologue of the fission yeast cell cycle control gene cdc2. Nature. 1987;327:31-5.

285. Draetta G, Brizuela L, Potashkin J, Beach D. Identification of $\mathrm{p} 34$ and $\mathrm{p} 13$, human homologs of the cell cycle regulators of fission yeast encoded by cdc2+ and suc1+. Cell. 1987;50:319-25.

286. Brown NR, Korolchuk S, Martin MP, Stanley WA, Moukhametzianov R, Noble ME, et al. CDK1 structures reveal conserved and unique features of the essential cell cycle CDK. Nat Commun. 2015;6:6769.

287. Malumbres M. Cyclin-dependent kinases. Genome Biol. 2014; $15: 122$

288. Wood DJ, Endicott JA. Structural insights into the functional diversity of the CDK-cyclin family. Open Biol. 2018;8.

289. Enserink JM, Kolodner RD. An overview of Cdk1-controlled targets and processes. Cell Div. 2010;5:11.

290. Conti M. Phosphodiesterases and regulation of female reproductive function. Curr Opin Pharmacol. 2011;11:665-9.

291. Azevedo MF, Faucz FR, Bimpaki E, Horvath A, Levy I, de Alexandre RB, et al. Clinical and molecular genetics of the phosphodiesterases (PDEs). Endocr Rev. 2014;35:195-233.

292. Shitsukawa K, Andersen CB, Richard FJ, Horner AK, Wiersma A, van Duin $\mathrm{M}$, et al. Cloning and characterization of the cyclic guanosine monophosphate-inhibited phosphodiesterase PDE3A expressed in mouse oocyte. Biol Reprod. 2001;65:188-96.

293. Masciarelli S, Horner K, Liu C, Park SH, Hinckley M, Hockman $\mathrm{S}$, et al. Cyclic nucleotide phosphodiesterase 3A-deficient mice as a model of female infertility. J Clin Invest. 2004;114:196-205.

294. Han SJ, Conti M. New pathways from PKA to the Cdc2/cyclin B complex in oocytes: Wee1B as a potential PKA substrate. Cell Cycle. 2006;5:227-31.

295. Kang H, Hwang SC, Park YS, Oh JS. Cdc25B phosphatase participates in maintaining metaphase II arrest in mouse oocytes. Mol Cell. 2013;35:514-8.

296. Oh JS, Susor A, Schindler K, Schultz RM, Conti M. Cdc25A activity is required for the metaphase II arrest in mouse oocytes. J Cell Sci. 2013;126:1081-5.

297. Pirino G, Wescott MP, Donovan PJ. Protein kinase A regulates resumption of meiosis by phosphorylation of Cdc25B in mammalian oocytes. Cell Cycle. 2009;8:665-70.

298. Schindler K, Schultz RM. The CDC14A phosphatase regulates oocyte maturation in mouse. Cell Cycle. 2009;8:1090-8.

299. Han SJ, Chen R, Paronetto MP, Conti M. Wee1B is an oocytespecific kinase involved in the control of meiotic arrest in the mouse. Curr Biol. 2005;15:1670-6.

300. Parker LL, Atherton-Fessler S, Piwnica-Worms H. p107wee1 is a dual-specificity kinase that phosphorylates p34cdc2 on tyrosine 15. Proc Natl Acad Sci U S A. 1992;89:2917-21.

301. Adhikari D, Zheng W, Shen Y, Gorre N, Ning Y, Halet G, et al. Cdk1, but not Cdk2, is the sole Cdk that is essential and sufficient to drive resumption of meiosis in mouse oocytes. Hum Mol Genet. 2012;21:2476-84. 
302. Adhikari D, Liu K, Shen Y. Cdk1 drives meiosis and mitosis through two different mechanisms. Cell Cycle. 2012;11:2763-4.

303. Hunt T. Maturation promoting factor, cyclin and the control of Mphase. Curr Opin Cell Biol. 1989;1:268-74.

304. Sun SC, Kim NH. Spindle assembly checkpoint and its regulators in meiosis. Hum Reprod Update. 2012;18:60-72.

305. Bennabi I, Terret ME, Verlhac MH. Meiotic spindle assembly and chromosome segregation in oocytes. J Cell Biol. 2016;215:611-9.

306. Davydenko O, Schultz RM, Lampson MA. Increased CDK1 activity determines the timing of kinetochore-microtubule attachments in meiosis I. J Cell Biol. 2013;202:221-9.

307. Musacchio A, Salmon ED. The spindle-assembly checkpoint in space and time. Nat Rev Mol Cell Biol. 2007;8:379-93.

308. Gorbsky GJ. The spindle checkpoint and chromosome segregation in meiosis. FEBS J. 2015;282:2471-87.

309. Jones KT. Meiosis in oocytes: predisposition to aneuploidy and its increased incidence with age. Hum Reprod Update. 2008;14:143-58.

310. Caburet S, Arboleda VA, Llano E, Overbeek PA, Barbero JL, Oka $\mathrm{K}$, et al. Mutant cohesin in premature ovarian failure. N Engl J Med. 2014;370:943-9.

311. Rosenwaks Z. Introduction: biomarkers of embryo viability: the search for the "holy grail" of embryo selection. Fertil Steril. 2017;108:719-21.

312. Albertini DF, Sanfins A, Combelles CM. Origins and manifestations of oocyte maturation competencies. Reprod BioMed Online. 2003;6:410-5.

313. Franasiak JM, Forman EJ, Hong KH, Werner MD, Upham KM, Treff NR, et al. The nature of aneuploidy with increasing age of the female partner: a review of 15,169 consecutive trophectoderm biopsies evaluated with comprehensive chromosomal screening. Fertil Steril. 2014;101:656-63 e651.

314. Hassold T, Hunt P. To err (meiotically) is human: the genesis of human aneuploidy. Nat Rev Genet. 2001;2:280-91.

315. Jones KT, Lane SI. Molecular causes of aneuploidy in mammalian eggs. Development. 2013;140:3719-30.

316. Nagaoka SI, Hassold TJ, Hunt PA. Human aneuploidy: mechanisms and new insights into an age-old problem. Nat Rev Genet. 2012;13:493-504.

317. Webster A, Schuh M. Mechanisms of aneuploidy in human eggs. Trends Cell Biol. 2017;27:55-68.

318. Holubcova Z, Blayney M, Elder K, Schuh M. Human oocytes. Error-prone chromosome-mediated spindle assembly favors chromosome segregation defects in human oocytes. Science. 2015;348:1143-7.

319. Zuccotti M, Merico V, Cecconi S, Redi CA, Garagna S. What does it take to make a developmentally competent mammalian egg? Hum Reprod Update. 2011;17:525-40.

320. Reader KL, Stanton JL, Juengel JL. The role of oocyte organelles in determining developmental competence. Biology. 2017;6.

321. Brown HM, Dunning KR, Sutton-McDowall M, Gilchrist RB, Thompson JG, Russell DL. Failure to launch: aberrant cumulus gene expression during oocyte in vitro maturation. Reproduction. 2017;153:R109-20.

322. Chen J, Torcia S, Xie F, Lin CJ, Cakmak H, Franciosi F, et al. Somatic cells regulate maternal mRNA translation and developmental competence of mouse oocytes. Nat Cell Biol. 2013;15: 1415-23.

323. Conti M, Franciosi F. Acquisition of oocyte competence to develop as an embryo: integrated nuclear and cytoplasmic events. Hum Reprod Update. 2018;24:245-66.

324. Labrecque R, Sirard MA. The study of mammalian oocyte competence by transcriptome analysis: progress and challenges. Mol Hum Reprod. 2014;20:103-16.
325. Virant-Klun I, Knez K, Tomazevic T, Skutella T. Gene expression profiling of human oocytes developed and matured in vivo or in vitro. Biomed Res Int. 2013;2013:879489.

326. Bermudez MG, Wells D, Malter H, Munne S, Cohen J, Steuerwald NM. Expression profiles of individual human oocytes using microarray technology. Reprod BioMed Online. 2004;8:325-37.

327. Kocabas AM, Crosby J, Ross PJ, Otu HH, Beyhan Z, Can H, et al. The transcriptome of human oocytes. Proc Natl Acad Sci U S A. 2006;103:14027-32.

328. Jones GM, Cram DS, Song B, Magli MC, Gianaroli L, LachamKaplan O, et al. Gene expression profiling of human oocytes following in vivo or in vitro maturation. Hum Reprod. 2008;23: 1138-44.

329. Zheng P, Patel B, McMenamin M, Moran E, Paprocki AM, Kihara M, et al. Effects of follicle size and oocyte maturation conditions on maternal messenger RNA regulation and gene expression in rhesus monkey oocytes and embryos. Biol Reprod. 2005;72:890-7.

330. Schramm RD, Paprocki AM, VandeVoort CA. Causes of developmental failure of in-vitro matured rhesus monkey oocytes: impairments in embryonic genome activation. Hum Reprod. 2003;18: 826-33.

331. Braude P, Bolton V, Moore S. Human gene expression first occurs between the four- and eight-cell stages of preimplantation development. Nature. 1988;332:459-61.

332. Ferraretti AP, La Marca A, Fauser BC, Tarlatzis B, Nargund G, Gianaroli L. Definition EwgoPOR. ESHRE consensus on the definition of 'poor response' to ovarian stimulation for in vitro fertilization: the Bologna criteria. Hum Reprod. 2011;26:1616-24.

333. Gilchrist RB, Thompson JG. Oocyte maturation: emerging concepts and technologies to improve developmental potential in vitro. Theriogenology. 2007;67:6-15.

334. Edwards RG. Maturation in vitro of human ovarian oocytes. Lancet. 1965;2:926-9.

335. Maller JL, Krebs EG. Progesterone-stimulated meiotic cell division in Xenopus oocytes. Induction by regulatory subunit and inhibition by catalytic subunit of adenosine $3^{\prime}: 5^{\prime}$ monophosphate-dependent protein kinase. J Biol Chem. 1977;252:1712-8.

336. Nogueira D, Cortvrindt R, De Matos DG, Vanhoutte L, Smitz J. Effect of phosphodiesterase type 3 inhibitor on developmental competence of immature mouse oocytes in vitro. Biol Reprod. 2003;69:2045-52.

337. Luciano AM, Franciosi F, Modina SC, Lodde V. Gap junctionmediated communications regulate chromatin remodeling during bovine oocyte growth and differentiation through cAMPdependent mechanism(s). Biol Reprod. 2011;85:1252-9.

338. Kawashima I, Okazaki T, Noma N, Nishibori M, Yamashita Y, Shimada M. Sequential exposure of porcine cumulus cells to FSH and/or LH is critical for appropriate expression of steroidogenic and ovulation-related genes that impact oocyte maturation in vivo and in vitro. Reproduction. 2008;136:9-21.

339. Aktas H, Wheeler MB, First NL, Leibfried-Rutledge ML. Maintenance of meiotic arrest by increasing [cAMP]i may have physiological relevance in bovine oocytes. J Reprod Fertil. 1995;105:237-45.

340. Funahashi H, Cantley TC, Day BN. Synchronization of meiosis in porcine oocytes by exposure to dibutyryl cyclic adenosine monophosphate improves developmental competence following in vitro fertilization. Biol Reprod. 1997;57:49-53.

341. Li HJ, Sutton-McDowall ML, Wang X, Sugimura S, Thompson JG, Gilchrist RB. Extending prematuration with cAMP modulators enhances the cumulus contribution to oocyte antioxidant defence and oocyte quality via gap junctions. Hum Reprod. 2016;31: 810-21. 
342. Prochazka R, Blaha M, Nemcova L. Significance of epidermal growth factor receptor signaling for acquisition of meiotic and developmental competence in mammalian oocytes. Biol Reprod. 2017;97:537-49.

343. Ritter LJ, Sugimura S, Gilchrist RB. Oocyte induction of EGF responsiveness in somatic cells is associated with the acquisition of porcine oocyte developmental competence. Endocrinology. 2015;156:2299-312.

344. Hussein TS, Thompson JG, Gilchrist RB. Oocyte-secreted factors enhance oocyte developmental competence. Dev Biol. 2006;296: 514-21.

345. Yeo CX, Gilchrist RB, Thompson JG, Lane M. Exogenous growth differentiation factor 9 in oocyte maturation media enhances subsequent embryo development and fetal viability in mice. Hum Reprod. 2008;23:67-73.

346. Sugimura S, Ritter LJ, Sutton-McDowall ML, Mottershead DG, Thompson JG, Gilchrist RB. Amphiregulin co-operates with bone morphogenetic protein 15 to increase bovine oocyte developmental competence: effects on gap junction-mediated metabolite supply. Mol Hum Reprod. 2014;20:499-513.

347. Santiquet NW, Greene AF, Becker J, Barfield JP, Schoolcraft WB, Krisher RL. A pre-in vitro maturation medium containing cumulus oocyte complex ligand-receptor signaling molecules maintains meiotic arrest, supports the cumulus oocyte complex and improves oocyte developmental competence. Mol Hum Reprod. 2017;23: 594-606.

348. Edwards RG, Bavister BD, Steptoe PC. Early stages of fertilization in vitro of human oocytes matured in vitro. Nature. 1969;221: $632-5$.

349. Cha KY, Koo JJ, Ko JJ, Choi DH, Han SY, Yoon TK. Pregnancy after in vitro fertilization of human follicular oocytes collected from nonstimulated cycles, their culture in vitro and their transfer in a donor oocyte program. Fertil Steril. 1991;55:109-13.

350. Trounson A, Wood C, Kausche A. In vitro maturation and the fertilization and developmental competence of oocytes recovered from untreated polycystic ovarian patients. Fertil Steril. 1994;62:353-62.

351. Chang EM, Song HS, Lee DR, Lee WS, Yoon TK. In vitro maturation of human oocytes: its role in infertility treatment and new possibilities. Clin Exp Reprod Med. 2014;41:41-6.

352. Fadini R, Mignini Renzini M, Dal Canto M, Epis A, Crippa M, Caliari I, et al. Oocyte in vitro maturation in normo-ovulatory women. Fertil Steril. 2013;99:1162-9.

353. Practice Committees of the American Society for Reproductive M, the Society for Assisted Reproductive T. In vitro maturation: a committee opinion. Fertil Steril. 2013;99:663-6.

354. Smitz JE, Thompson JG, Gilchrist RB. The promise of in vitro maturation in assisted reproduction and fertility preservation. Semin Reprod Med. 2011;29:24-37.

355. Trounson A, Anderiesz C, Jones G. Maturation of human oocytes in vitro and their developmental competence. Reproduction. 2001;121:51-75.
356. Combelles CM, Cekleniak NA, Racowsky C, Albertini DF. Assessment of nuclear and cytoplasmic maturation in in-vitro matured human oocytes. Hum Reprod. 2002;17:1006-16.

357. Gremeau AS, Andreadis N, Fatum M, Craig J, Turner K, McVeigh $\mathrm{E}$, et al. In vitro maturation or in vitro fertilization for women with polycystic ovaries? A case-control study of 194 treatment cycles. Fertil Steril. 2012;98:355-60.

358. Junk SM, Yeap D. Improved implantation and ongoing pregnancy rates after single-embryo transfer with an optimized protocol for in vitro oocyte maturation in women with polycystic ovaries and polycystic ovary syndrome. Fertil Steril. 2012;98:888-92.

359. Ortega-Hrepich C, Stoop D, Guzman L, Van Landuyt L, Tournaye H, Smitz J, et al. A "freeze-all" embryo strategy after in vitro maturation: a novel approach in women with polycystic ovary syndrome? Fertil Steril. 2013;100:1002-7.

360. Walls ML, Ryan JP, Keelan JA, Hart R. In vitro maturation is associated with increased early embryo arrest without impairing morphokinetic development of useable embryos progressing to blastocysts. Hum Reprod. 2015;30:1842-9.

361. Walls ML, Hunter T, Ryan JP, Keelan JA, Nathan E, Hart RJ. In vitro maturation as an alternative to standard in vitro fertilization for patients diagnosed with polycystic ovaries: a comparative analysis of fresh, frozen and cumulative cycle outcomes. Hum Reprod. 2015;30:88-96.

362. Fadini R, Mignini Renzini M, Guarnieri T, Dal Canto M, De Ponti E, Sutcliffe A, et al. Comparison of the obstetric and perinatal outcomes of children conceived from in vitro or in vivo matured oocytes in in vitro maturation treatments with births from conventional ICSI cycles. Hum Reprod. 2012;27:3601-8.

363. Foix-L'Helias L, Grynberg M, Ducot B, Frydman N, Kerbrat V, Bouyer J, et al. Growth development of French children born after in vitro maturation. PLoS One. 2014;9:e89713.

364. Buckett WM, Chian RC, Holzer H, Dean N, Usher R, Tan SL. Obstetric outcomes and congenital abnormalities after in vitro maturation, in vitro fertilization, and intracytoplasmic sperm injection. Obstet Gynecol. 2007;110:885-91.

365. Soderstrom-Anttila V, Salokorpi T, Pihlaja M, Serenius-Sirve S, Suikkari AM. Obstetric and perinatal outcome and preliminary results of development of children born after in vitro maturation of oocytes. Hum Reprod. 2006;21:1508-13.

366. Roesner S, von Wolff M, Elsaesser M, Roesner K, Reuner G, Pietz J, et al. Two-year development of children conceived by IVM: a prospective controlled single-blinded study. Hum Reprod. 2017;32:1341-50.

Publisher's note Springer Nature remains neutral with regard to jurisdictional claims in published maps and institutional affiliations. 